\title{
Long-term trends in upper ocean structure and meridional circulation of the Southern Ocean south of Australia derived from the SODA reanalysis
}

\author{
Barbara M. Johnston*and Albert J. Gabric \\ Australian Rivers Institute \\ Griffith University \\ Nathan \\ Queensland \\ Australia, 4111
}

March 29, 2010

*Corresponding author. Email: Barbara.Johnston@griffith.edu.au. 


\begin{abstract}
Decadal-scale changes in the meridional circulation of the Southern Ocean south of Australia are studied, over the period 1958-2005, using Simple Ocean Data Assimilation (SODA) reanalysis data. Upper Circumpolar Deep Water (UCDW) is found to upwell nearer to the surface over time, while the mixed layer (ML) is found to deepen, leading to an increase in the number of times that UCDW intrudes into the ML. This entrainment of nutrients, especially iron, into the ML from UCDW, is crucial for primary production and appears to occur predominantly in summer/autumn, contrary to previous reports.

ML temperature, density and salinity all show increasing trends in almost all seasons and latitudinal zones within the study region. A notable exception to the general increase in temperature occurs in the most southerly zone $60-65^{\circ} \mathrm{S}$ in summer. An explanation for this apparent anomaly could be related to increased winds (in conjunction with the increasing trend in the Southern Annular Mode), which mix remnant winter water into the ML, negating the surface temperature increase.

Unlike trends in ML variables, trends in UCDW variables appear to be decoupled from the surface trends and occur on time-scales that may be centennial rather than decadal.
\end{abstract}




\section{Introduction}

Insights into decadal-scale changes in the meridional circulation in the Southern Ocean (SO) are important from the point of view of understanding climate change in that region and globally. For example, a strengthening in the meridional upwelling might lead to higher primary production in the high latitudes, due to increased upwelling of nutrients and therefore to increased drawdown of $\mathrm{CO}_{2}$ via the biological pump (Lovenduski and Gruber, 2005). At the same time, deep waters with higher concentrations of dissolved inorganic carbon would be upwelled, leading to an outgassing of natural $\mathrm{CO}_{2}$ to the atmosphere (Le Quere et al., 2007; Lovenduski et al., 2007). In addition to these, trends in other factors, such as in the strength and position of the westerly winds, ocean temperature, timing and extent of ice melt and ocean stratification need to be considered in developing an understanding of past and future climate change.

The conventional view (Speer et al., 2000) regards the meridional circulation in the SO as consisting of upper and lower cells, where the upper (Deacon) cell involves water upwelling southwards to the near-surface along steeply tilted isopycnals, moving northward by surface Ekman transport and then sinking to form Antarctic Intermediate Water (AAIW) or Subantarctic Mode Water (SAMW). This meridional upwelling takes place against a background of intense zonal flow in the Antarctic Circumpolar Current (ACC) and occurs south of the Polar Front (PF) (Hoppema et al., 2003; Sokolov and Rintoul, 2007).

Circumpolar Deep Water, comprised of Upper (UCDW) and Lower (LCDW) Circumpolar Deep Water, is the most extensive water mass in the ACC (Gordon, 1967). UCDW is characterised by a nutrient maximum and an oxygen minimum, making it critical for primary production when it reaches the upper ocean. It is supplied mainly from the eastern south Pacific Ocean and the western Indian Ocean (Callahan, 1972; Park et al., 1993). On the other hand, LCDW is oxygen-rich and is characterised by a salinity maximum and a nutrient minimum, whose source is North Atlantic Deep Water (NADW) (Patterson and Whitworth, 1990; Park et al., 1993).

Changes in the westerly winds, which drive the ACC, will not only potentially affect the position and strength of the ACC, but also the upwelling of UCDW, because of variations in the Ekman transport. The Southern Annular Mode (SAM) is the most important mode of climate variability in the Southern Hemisphere middle and high latitudes on intra-seasonal and inter-annual timescales (Lovenduski and Gruber, 2005) and is associated with north-south movements of the westerly winds. Changes in SAM have been linked to changes in ocean circulation (Hall and Visbeck, 2002), seaice (Lefebvre et al., 2004), and carbon dioxide uptake and biological productivity (Lovenduski and Gruber, 2005; Lovenduski et al., 2007; Lenton and Matear, 2007).

The SAM index (Marshall, 2003; Visbeck, 2009) has been moving towards a more positive mode since the 1970s (Thompson and Solomon, 2002), indicating a poleward intensification of the SH winds. However, while the SAM is generally considered to be zonally symmetric, recent studies have found that the wind response is not (Drost and England, 2009) and neither is the oceanic response of the fronts (Sallee et al., 2008) and thus its effect differs in the various regions of the SO. This work concentrates on the SO south of Australia, where the above-mentioned study (Sallee et al., 2008) found that the trend associated with more positive SAM results in an intensification, but no distinct meridional shift, of the ACC fronts. Another factor to take into account is the fact that, when considered on a seasonal scale, the SAM shows significant positive trends only in summer (DJF) and autumn (MAM), over the period 1957-2004 (Marshall, 2007).

It is also necessary to consider the effect of the El Niño/Southern Oscillation (ENSO), which, while it is a tropical coupled system, still has an impact in our study region (Holbrook and Bindoff, 1997; L'Heureux and Thompson, 2006).

Given the sparse data availability in the SO prior to the Argo period and the consequent difficulty in establishing trends on a decadal basis, this paper uses reanalysis data from the Simple Ocean Data 
Assimilation (SODA) 2.0.2/2.0.3 reanalysis to look at monthly climatologies and seasonal trends. These trends are over the period 1958-2005, and are in mixed layer (ML) variables, such as depth, temperature, density and salinity, as well as similar UCDW variables. In addition, trends in the location of the maximum wind stress, stratification, Ekman pumping, Ekman transport, UCDW upwelling depth and the southern-most extent of UCDW are examined. Finally, connections between wind stress and these variables are discussed.

\section{Methods}

The region studied in this work is the Australian sector of the Southern Ocean $\left(110-160^{\circ} \mathrm{E}, 40-65^{\circ} \mathrm{S}\right)$ and this is shown in Figure 1, which presents sea surface temperature, SST, (estimated at $5 \mathrm{~m}$ depth) in January 2000, taken from SODA, as well as mean positions for the Polar Front (PF) and Southern Boundary of the ACC (Orsi and Ryan, 2001, updated 2006). Approximate mean positions for the other ACC fronts in this region can be taken from those identified on the WOCE SR3 line (approximately $140^{\circ} \mathrm{E}$ ) (Sokolov and Rintoul, 2002): Subantarctic Fronts (SAF) 1 and 2 (50.5 ${ }^{\circ} \mathrm{S}$ and $\left.52^{\circ} \mathrm{S}\right)$ and the Southern ACC front (sACCf) $\left(62-64^{\circ} \mathrm{S}\right)$. Along this line, the sea ice zone extends to approximately $60^{\circ} \mathrm{S}$, with sea ice retreat to $65^{\circ} \mathrm{S}$ (Sokolov, 2008).

\subsection{SODA}

The SODA package (Carton et al., 2000, 2005; Carton and Giese, 2008) is a reanalysis of ocean climate variability that begins with a state forecast produced by a General Circulation Model based on POP (Parallel Ocean Program) numerics (Smith et al., 1992), forced by ERA-40 winds, from the European Centre for Medium-Range Weather Forecasts 40-year reanalysis (Uppala et al., 2005). This work uses the SODA 2.0.2/2.0.3 datasets, which cover the period from 1958-2001/2002-2005 and consist of sea surface heights, surface wind stresses, monthly zonal, meridional and vertical velocity fields, as well as temperature and salinity, which are presented on an eddy-permitting $0.5^{\circ} \times 0.5^{\circ} \times 40$ depth level (from $5 \mathrm{~m}$ to about $5500 \mathrm{~m}$, with $10 \mathrm{~m}$ resolution in the top $100 \mathrm{~m}$ ) global grid. The SODA 2.0.3 reanalysis is different from the one for the earlier period in that it uses QuikSCAT (Spencer et al., 2000) winds rather than ERA-40 winds. This is a potential source of error in this work, although the two have been used together in other studies, for example (Schott et al., 2008, 2009), and examination of the aggregated time series used here does not show any particular biases.

The reanalysis is evaluated by comparisons with independent observations, such as the historical archive of hydrographic profiles, supplemented by ship intake measurements, moored hydrographic observations, remotely sensed SST and sea level. Comparisons of forecasts and observations, using tide gauge level records and satellite altimetry, are also carried out (Carton et al., 2000). SODA uses a sequential data estimation scheme to change temperature and salinity in the model ocean in order to accommodate hydrographic observations, which are restricted to depths shallower than about 1000 $\mathrm{m}$ for assimilation, due to the scarcity of observations below that depth. Freshwater fluxes since 1979 come from the Global Precipitation Climatology Project precipitation data and evaporation from bulk formulae (Schott et al., 2009). The vertical diffusion of momentum, heat and salt are carried out using KPP mixing with modifications to address issues such as diurnal heating (Carton and Giese, 2008). Vertical velocity is calculated using the continuity equation (Smith and Gent, May, 2002: revised May 2004) and does not include entrainment.

The core of UCDW can be identified (Sievers and Nowlin, 1984; Orsi et al., 1995) by $\left[\mathrm{O}_{2}\right]<4.5$ $\mathrm{ml} \mathrm{l^{-1 }}$ at density values $27.35 \mathrm{~kg} \mathrm{~m}^{-3}<\sigma_{\theta}<27.75 \mathrm{~kg} \mathrm{~m}^{-3}$, where $\left[\mathrm{O}_{2}\right]$ is oxygen concentration and $\sigma_{\theta}$ is potential density anomaly. This is is equivalent to the density criterion with temperature, $\theta>1.5^{\circ} \mathrm{C}$ (Orsi et al., 1995; Sokolov and Rintoul, 2002) and gives a salinity range of between 34.5 
and 34.7. UCDW is identified in SODA using the density and temperature criteria above. An example of this is given in Figure 2, which shows UCDW along $140^{\circ} \mathrm{E}$ in February 1997. A temperature minimum layer (remnant winter water), overlaid by a shallow warm mixed layer created by summer warming, can be seen above UCDW, which is located in the temperature maximum layer (Sokolov and Rintoul, 2007).

\subsection{Time Series}

The Australian sector from $110-160^{\circ} \mathrm{E}$ to $40-65^{\circ} \mathrm{S}$, studied here, is divided latitudinally into 5-degree zones. Spatial averaging of UCDW variables, such as vertical velocity, temperature, density and salinity is computed over the depth of UCDW and over the particular latitudinal zone, for example $\left(110-160^{\circ} \mathrm{E}, 50-55^{\circ} \mathrm{S}\right)$. Temporal averages are computed at monthly and seasonal (where the year is divided into four sets of three months, December, January, February (DJF) and so on) scales. Examples of such time series for $1958-2005$ in the $55-60^{\circ} \mathrm{S}$ zone in summer(DJF), for mixed layer depth and mean wind stress, can be seen in Figure 3. Medians by month for these SODA time series (1958-2005) are used to produce monthly climatologies.

Mixed layer depths (MLDs) are calculated in SODA using the criterion of an absolute temperature difference of $0.2^{\circ} \mathrm{C}$ from the surface (Montegut et al., 2004). Temperature, density and salinity in the ML are then calculated as an average over the MLD at each grid point and then averaged over the latitudinal region by month to produce time series. For comparison purposes only, MLDs based on the density criterion of a $0.125 \mathrm{~kg} \mathrm{~m}^{-3}$ change in the potential density from the ocean surface (Monterey and Levitus, 1997), $\operatorname{MLD}(\sigma)$, are also calculated in SODA. Time series are also calculated for temperature, density and salinity based on $\operatorname{MLD}(\sigma)$ and also for sea surface variables (estimated at $5 \mathrm{~m}$ depth).

Wind stress is calculated as the magnitude of the SODA wind stress vector $\boldsymbol{\tau}=\left(\tau_{x}^{2}+\tau_{y}^{2}\right)^{\frac{1}{2}}$, from the SODA values for zonal and meridional wind stress, respectively. Maximum wind stress over the whole region, as well as the latitude at which the maximum wind stress occurs, are then found, as well as mean wind stress for each latitudinal zone.

Other variables considered include stratification at the base of the mixed layer, which is calculated using the Brunt-Vaissala Frequency squared $\left(N^{2}\right)$,

$$
N^{2}=-\frac{g}{\rho_{0}} \frac{\partial \sigma_{\theta}}{\partial z}
$$

where $g$ is the acceleration due to gravity and $\rho_{0}$ is the average density for the zone. In addition the Ekman pumping rate, $E$, is defined as

$$
E=-\operatorname{curl}\left(\frac{\boldsymbol{\tau}}{\rho_{0} f}\right)
$$

where $f$ is the Coriolis parameter. Related to the Ekman pumping rate is the northward Ekman transport, $Q_{E}$, which can be calculated as

$$
Q_{E}=-\frac{X \tau_{x}}{\rho_{0} f}
$$

where $X$ is the east-west distance across which the transport is calculated.

\subsection{Trends}

Trends and their significance in seasonal (DJF, MAM, JJA and SON) time series are estimated using the non-parametric seasonal Sen slope (Gilbert, 1987), a generalisation of Sen's estimator of slope, 
and the seasonal Kendall test (Hirsch et al., 1982), a generalisation of the Mann-Kendall test, which is not affected by seasonal cycles in the data. The non-parametric estimate of the slope is preferable to linear least squares regression due to its insensitivity to outliers (Gilbert, 1987; Hess et al., 2001).

The test involves computing the Mann-Kendall test statistic and its variance separately for each month ('season'), with the data collected over years, and then summing these seasonal statistics to produce a Z statistic (Gilbert, 1987). Here the test is applied to each set of 3 months within a particular seasonal time series (eg. DJF) of 144 points, comprised of 48 years worth of 3 months of data. The seasonal Sen's slope is then used to estimate a linear trend. Trends at the $95 \%$ confidence level are reported here as 'significant'.

\subsection{Correlations}

Correlations between two Southern Hemisphere atmospheric indices, the SAM and the multivariate ENSO Index (MEI), and the wind stress are performed. In addition, correlations between mean wind stress and stratification, UCDW variables and ML variables are calculated. Correlations are found only after the time series are detrended and averaged time series (one point per season, as in Figure 3 ) are used. Indices to measure the SAM, prior to the satellite era (1979), have been constructed by Marshall (2003) and also Visbeck (Hall and Visbeck, 2002; Visbeck, 2009) using Southern Hemisphere atmospheric pressure observations from stations situated either near $40^{\circ} \mathrm{S}$ or $65^{\circ} \mathrm{S}$. Positive values of the SAM index indicate lower than normal atmospheric pressures over the polar regions, while negative values mean the opposite (that is, higher than normal pressures over the polar regions). The index constructed by Marshall (2003) is used here because both seasonal and annual values are available. The MEI (Wolter, 1987; Wolter and Timlin, 1993) is based on observations of sea-level pressure, zonal and meridional surface wind components, SST and total cloudiness fraction of the sky, taken over the tropical Pacific. The MEI values are calculated as the first unrotated principal component of all these fields combined, computed for twelve sliding bi-monthly seasons (that is, December/January, January/February and so on) and then standardised with respect to each season and to the 1950-1993 reference period. For seasonal correlation purposes, DJF is taken to be November/December, December/January, January/February. Positive values of the MEI represent the warm ENSO phase (El Niño).

\section{Results and Discussion}

\subsection{Comparison of SODA with Hydrographic data}

In order to assess SODA's skill at representing hydrographic data in the Australian region of the SO, temperature and salinity plots were produced from SODA and compared with plots produced from hydrographic data collected along the SR3 track (approximately $140^{\circ} \mathrm{E}$ ) in November 2001 (Sokolov and Rintoul, 2007). These plots, given in Figures 4 and 5 (note the different colour maps) show that the SODA data is a very close match for the actual temperature data and a good match for the salinity data, although SODA puts the 34.5 contour at a lower depth, than in the observations, in the higher latitudes. It should be noted, however, that the comparison of SODA with the observational data does not really illustrate SODA's skill, since here SODA is reproducing data that has already been assimilated into the model. It would seem that such an illustration is not possible since it would require an independent dataset that has not already been assimilated into SODA. 


\subsection{SAM and MEI trends}

The SAM index is known to have been moving towards a more positive polarity since the 1970 s (Thompson and Solomon, 2002; Marshall, 2003). However, as mentioned in the Introduction, this is not true for all seasons (Marshall, 2007). Using the data produced by Marshall (2003) applied to the period under study here (1958-2005) it is found that the index shows a positive trend for DJF and MAM only, in agreement with Marshall (2007), who analysed the period 1957-2004. An example of the SAM index for DJF can be seen in Figure 3. When a similar analysis for 1958-2005 was conducted for the MEI, it was found that the index shows a significant positive trend in MAM and JJA only, meaning that the index is moving to a more 'El Niño-like' state.

\subsection{Correlations}

\subsubsection{Correlations between SAM/MEI and mean wind stress}

The aim of this section is to determine the effect of two of the major Southern Hemisphere atmospheric indices, SAM and MEI, on the winds in the region under consideration. Correlations between the SAM/MEI indices and the mean wind stress are given in Table 1, for each latitudinal zone and season. Strong correlations between SAM and mean wind stress can be seen in most seasons and zones, with positive correlations in the south and negative correlations in the north, due to the fact that positive SAM means stronger winds in the south, relative to the north.

The majority of the correlations between MEI and mean wind stress are positive and occur in the more northerly zones. There is also an intriguing (negative) correlation between MEI and mean wind stress in DJF in the most southerly zone. The opposite signs in the correlations between SAM and mean wind stress, and MEI and wind stress in $60-65^{\circ} \mathrm{S}$ and $40-45^{\circ} \mathrm{S}$ are consistent with studies that have found that ENSO and SAM indices are often anti-correlated (L'Heureux and Thompson, 2006). Another point to note is that there are a few season/zone combinations where there is a significant effect from both SAM and MEI on the mean wind stress.

\subsubsection{Correlations between mean wind stress and other variables}

An example of a positive correlation (0.78), between mean wind stress and MLD in the 55-60 $\mathrm{S}$ zone in DJF, can be seen in Figure 3, where there is also a significant correlation between SAM and mean wind stress (0.80). The relationship between the wind stress and other variables is summarised in Table 2, which presents significant correlations (and when they occur) between mean wind stress and various other variables. Ekman transport is not considered, as it is calculated using $\tau$. There are very few significant correlations between mean wind stress and UCDW variables, compared with the number that are associated with the ML. Also, correlations between mean wind stress and ML variables are positive for ML depth, density and salinity, but negative for temperature. Some interesting observations from Table 2 include the fact that the strongest correlations in any zone are all in DJF and that there are more ML correlations in DJF and MAM than in any other season.

\section{$3.4 \mathrm{UCDW}$}

\subsubsection{UCDW Climatological Means}

Annual means of SODA climatological values for UCDW variables are given in Table 3, where UCDW temperature, density and salinity values are the same for all seasons. The density (around $27.6 \mathrm{~kg} \mathrm{~m}^{-3}$ ), salinity (34.6) and temperature values (which are all above $1.5^{\circ} \mathrm{C}$ ) are all consistent 
with the definition of UCDW water mass characteristics from Section 2. UCDW temperatures decrease from $2.7^{\circ} \mathrm{C}$ for UCDW lying at depths of up to $2400 \mathrm{~m}$ in the $40-45^{\circ} \mathrm{S}$ zone to $1.9^{\circ} \mathrm{C}$ in the $60-65^{\circ} \mathrm{S}$ zone, presumably because UCDW is rising towards the surface and coming into contact with cooler water masses.

UCDW shoals as it upwells to the south, as can be seen in Figure 2 and also from the approximate depth ranges given in Table 3. The isopycnals begin to rise steeply near the Subantarctic Front (around $50^{\circ} \mathrm{S}$ ) and continue to rise, outcropping south of the Polar Front (between 55 and $65^{\circ} \mathrm{S}$ here). UCDW is found as far south as the Southern Boundary of the ACC (around $64^{\circ} \mathrm{S}$ in our region - see Figure 1), but no further south, since the Southern Boundary is defined (Orsi et al., 1995) as the poleward edge of the UCDW signal. The position of the Southern Boundary is consistent with the southern-most location of UCDW identified in SODA at around $64.5^{\circ} \mathrm{S}$ (moving as far south as $64.8^{\circ} \mathrm{S}$ in MAM, when the area is ice free). Vertical velocities in UCDW (Table 3), peak in the $50-55^{\circ} \mathrm{S}$ zone and then decrease as UCDW shoals upwards. UCDW is then entrained in the surface Ekman layer, which moves back towards the north, forming AAIW, when it downwells beneath the warmer SAMW (Speer et al., 2000). Climatological plots of the depth to which UCDW upwells (see Figure 6) indicate that there is a seasonal variation in this depth in the more southerly zones, with UCDW upwelling highest in March.

\subsubsection{UCDW Linear Trends (1958-2005)}

A summary table for the significant linear trends in UCDW variables can be found in Table 4. Since trends are obtained for a large number of time series (viz., seasonal time series for each variable and latitudinal zone), the data are summarised by presenting the maximum significant trend (over the four seasons), the seasons where there is a significant trend, and marking with an asterisk the time period to which the maximum trend applies. For example, ALL(MAM*) means that there are significant trends in all four seasons and that the maximum trend presented applies to the MAM time period. Maximum significant trends are also presented, as a percentage of (the absolute value of) the median value, in Table 8, for those variables where it is meaningful to do so.

It can be seen that UCDW vertical velocity is increasing in all seasons in the three most northerly zones (where UCDW is deep) and in MAM in the most southerly zone (where UCDW upwells). In the two most southerly zones $55-65^{\circ} \mathrm{S}$, UCDW is found to upwell closer to the surface in almost all seasons and decreases in density and salinity are found for the $60-65^{\circ} \mathrm{S}$ zone. In addition, UCDW is found to upwell further to the south over time in all seasons. The values for percentage trend, given in Table 8, are greatest for UCDW top depth and some vertical velocity and Ekman pumping rate values.

UCDW temperature is increasing for all seasons in the $60-65^{\circ} \mathrm{S}$ zone, but interestingly no significant trends are found in the $55-60^{\circ} \mathrm{S}$ zone. Another noteworthy result is the decreasing trend in UCDW temperature found in the three northerly zones. It might have been expected that UCDW would show increasing temperature in accordance with previous findings of increases in Southern Ocean temperatures (Aoki et al., 2003; Gille, 2002) and the trends in 60-65 ${ }^{\circ}$ S agree with this. However, this is not the case for the other zones and, since UCDW, north of $50^{\circ} \mathrm{S}$, lies at depths of up to $2400 \mathrm{~m}$ (see Table 3), the cooling trends found in its temperature may well be unrelated to warming in the upper ocean; they may, in fact, be indicative of trends in deep water further in the past, since it is believed that the time taken for NADW to move from the Northern Hemisphere and upwell as UCDW is of the order of centuries (Santoso et al., 2006). The above would perhaps also explain the lack of significant trends in $55-60^{\circ} \mathrm{S}$, where the cooling trend in the deeper water is counteracted by mixing with warming upper ocean water, during upwelling.

The above hypothesis that trends in UCDW are not related to surface trends is also supported by the lack of correlations between the mean wind stress and UCDW variables in Table 2. For example, there are no direct correlations between UCDW top depth and mean wind stress (nor are there lagged 
ones up to a 10 year lag - not presented) and neither are there direct nor lagged correlations between UCDW top depth and the Ekman pumping rate (not presented).

\subsection{Winds, stratification and Ekman variables}

\subsubsection{Climatological Wind Stress}

From Figure 7, it can be seen that the location of maximum wind stress, as well as the values of regional mean and maximum wind stress, varies seasonally with the Semi-Annual Oscillation. Peak wind stress occurs around April and September and these months also correspond to the most southerly locations of the maximum wind stress.

The maximum wind stress varies from $0.22 \mathrm{~N} \mathrm{~m}^{-2}$ in December/January to $0.29 \mathrm{~N} \mathrm{~m}^{-2}$ in April and September, dropping to $0.25 \mathrm{~N} \mathrm{~m}^{-2}$ in June. The mean wind stress follows a similar pattern, with values in the range $0.12-0.18 \mathrm{~N} \mathrm{~m}^{-2}$. The location of the maximum wind stress moves from $49.5^{\circ} \mathrm{S}$ in December/January to $54.3^{\circ} \mathrm{S}$ in April/May, moving northwards to $52.3^{\circ} \mathrm{S}$ in July.

A similar climatological plot for mean wind stress by latitudinal zone (not presented), shows low values of wind stress in the $60-65^{\circ} \mathrm{S}$ zone, which is close to the latitudes where the westerly winds give way to the Easterlies near the Antarctic continent. The wind stress increases to the north reaching a maximum between 50 and $55^{\circ} \mathrm{S}$, as discussed above, and then decreases again.

\subsubsection{Linear trends (1958-2005) in winds}

Increasing trends for maximum wind stress are found for DJF and MAM only (see bottom of Table 5), consistent with increasing trends in SAM in the same seasons (see Section 3.2), while no significant trends are found for the location of maximum wind stress. Trends in mean wind stress by latitudinal zone (presented in Table 5) are all positive, indicating increases in the mean wind stress, particularly in DJF, except for the $55-60^{\circ} \mathrm{S}$ zone. Finally, no trends are found in the location where $\operatorname{curl}(\tau)$ is equal to zero.

Given that there are strong positive correlations between SAM and mean wind stress in all seasons in 50-65 $\mathrm{S}$ (see Table 1) and that SAM shows an increasing trend in DJF and MAM (see Section 3.2), it is somewhat surprising that the mean wind stress, unlike the maximum wind stress, shows a significant increasing trend in DJF only and not in $55-60^{\circ} \mathrm{S}$ at all. This is possibly due to a confounding effect from ENSO, since the MEI exhibits a positive trend in MAM (see Section 3.2).

Increasing SAM may also mean winds moving south (Thompson and Solomon, 2002), but recent work has found that the effect of SAM varies depending on the region (Sallee et al., 2008; Drost and England, 2009) and that, in $110-150^{\circ} \mathrm{E}$ (almost our study region) the winds will move north (Drost and England, 2009). We do not find a northerly trend, but do find that there is no significant trend in the position of the maximum wind stress.

\subsubsection{Climatological stratification and Ekman variables}

The monthly climatology for stratification at the base of the ML given by $N^{2}$ and presented in Figure 8, shows seasonal variation in stratification, with maximum stratification in February/March and minimum stratification in September-November. The more southerly zones reach their peak values later, due to ice melt and formation. The strongest stratification is found in the $60-65^{\circ} \mathrm{S}$ zone and stratification generally decreases to the north, with the exception being in DJF, where the strongest stratification is found in the $40-45^{\circ} \mathrm{S}$ zone.

The climatology for the Ekman pumping rate (not presented) shows decreases from positive values (upwelling) of around $2 \times 10^{-6} \mathrm{~ms}^{-2}$ in $60-65^{\circ} \mathrm{S}$, through zero where $\operatorname{curl}(\tau)$ is equal to 0 (between $53.5^{\circ} \mathrm{S}$ in summer and $55.3^{\circ} \mathrm{S}$ in winter) and moves to maximum negative values (downwelling) of 
around $-1 \times 10^{-6} \mathrm{~ms}^{-2}$ in $40-45^{\circ} \mathrm{S}$. The minimum pumping rate occurs in winter and generally peaks in April and September like the wind stress. However, only the southern-most zone follows the wind stress pattern in Figure 7, with a large decrease in summer values.

Peak climatological northward Ekman transport values for each latitudinal zone (not presented) occur around March and October, with minimum values in December, similar to the wind stress (see Figure 7). Values vary from around $1 \mathrm{~Sv}\left(10^{6} \mathrm{~m}^{3} \mathrm{~s}^{-1}\right)$ in $60-65^{\circ} \mathrm{S}$ to $5 \mathrm{~Sv}$ in $50-55^{\circ} \mathrm{S}$.

\subsubsection{Linear trends (1958-2005) in stratification and Ekman variables}

Data showing significant trends in stratification, upward Ekman pumping rate and northwards Ekman transport are also given in Table 5. No trends are given for upward Ekman pumping rate in 50-55 ${ }^{\circ} \mathrm{S}$ since in that region pumping varies interannually from upwelling to downwelling, nor north of $50^{\circ} \mathrm{S}$, since it is not is applicable there.

Trends in Table 5 show that the mean upward Ekman pumping rate is increasing in DJF in $55-65^{\circ} \mathrm{S}$ and MAM in $55-60^{\circ} \mathrm{S}$, but is decreasing in $60-65^{\circ} \mathrm{S}$ in SON. The final variable considered in Table 5 is the mean northward Ekman transport, which can be seen to be decreasing in $50-60^{\circ} \mathrm{S}$ in $\mathrm{SON}$ and increasing in DJF and JJA in the more northerly zones.

Stratification can be seen to decrease over time, although only in some seasons. An alternative measure for stratification (not presented here, but which is simply the density difference at $200 \mathrm{~m}$ and $5 \mathrm{~m}$ depth), shows a greater number of seasons where stratification is decreasing. The fact that there are so few correlations between stratification and mean wind stress in Table 2 seems to indicate that stratification is affected by factors other than wind stress, such as ML temperature and timing and extent of sea-ice melt (in the southern-most latitudes only).

\subsection{Mixed Layer variables}

\subsubsection{ML climatological means}

SODA summer and winter climatological values for ML variables, are given in Table 6. ML density increases and salinity decreases to the south, with salinity rising again slightly near the continent. ML temperatures and sea surface temperatures (SST) (not presented) decrease to the south, with SST temperatures generally higher than ML temperatures (by up to $0.4^{\circ} \mathrm{C}$ ), except in regions of ice formation.

MLD in the Southern Ocean follows a seasonal cycle (see Figure 6) with climatological maximum depths averaging around $150 \mathrm{~m}$ (with large interannual variations) in the $40-50^{\circ} \mathrm{S}$ (Subantarctic zone) between August and October, whereas south of this, the winter mixed layer shoals southward. Summer (DJF) MLD is nearly $50 \mathrm{~m}$ in the Subantarctic zone, shoaling to around $25 \mathrm{~m}$ near the Antarctic continent.

An investigation into MLD calculated using the less stringent density criterion, $\operatorname{MLD}(\sigma)$, found that $\operatorname{MLD}<\operatorname{MLD}(\sigma)$ for climatological values, in almost all zones. For example, in $60-65^{\circ} \mathrm{S}$, summer MLD is $28.8 \mathrm{~m}$ compared with $42.9 \mathrm{~m}$ for $\operatorname{MLD}(\sigma)$. In addition, the seasonal variation in $\operatorname{MLD}(\sigma)$ (not presented) is almost identical to that in Figure 6, although the $\operatorname{MLD}(\sigma)$ values are larger. These $\operatorname{MLD}(\sigma)$ depths are similar to those found by Sokolov (2008) using the ML climatology of Montegut et al. (2004).

\subsubsection{ML linear trends (1958-2005)}

With one exception, all significant trends found for ML variables and presented in Table 7, are positive, indicating increasing mixed layer depth, temperature, density and salinity in all seasons, except in the most northerly and most southerly zones. In the most southerly zone, the exceptions are in 
ML temperature in DJF and MAM and ML density in JJA and SON. ML depth found using the two criteria, MLD and $\operatorname{MLD}(\sigma)$ (not presented), shows similar trends in each case. The same is true for sea-surface temperature, salinity and density trends (not presented), when compared with their ML counterparts, although the trends are often a little larger for the sea-surface variables.

These results appear to be related to trends in wind stress, particularly in the more southerly zones, based on the strong correlations in Table 2 between mean wind stress and ML variables. In DJF, increasing wind stress contributes to a deepening in the ML, an increase in evaporation and a subsequent increase in salinity and density, as well as mixing of water of greater density into the ML. The negative correlation between ML temperature and mean wind stress in DJF and MAM is explained, in all but the most southerly zones, by the mixing of colder, deeper water into the ML (see Tables 3 and 6 for UCDW and ML temperatures). However, this effect is outweighed by surface heating, leading to increases in ML temperatures.

In $60-65^{\circ} \mathrm{S}$ a different situation arises in DJF and MAM, where there are no significant positive trends in ML temperature, unlike all other zones and seasons. An explanation for this in DJF in $60-65^{\circ} \mathrm{S}$ could be related to the presence in January-March of colder remnant water between the ML and UCDW (see Figure 2). Increasing winds (see Table 5) mix this colder water into the ML, where it counteracts the surface warming. The situation in MAM is different from DJF in that there is no negative correlation between mean wind stress and temperature there (see Table 2) and there is still a weakly significant (90\% confidence level) positive trend in ML temperature.

\subsection{Intrusion of UCDW into the Mixed Layer}

The frequency with which UCDW upwells into the mixed layer is important for the entrainment of nutrients (in particular, iron), which is thought to be critical for primary production (Martin et al., 1990; Hoppema et al., 2003). The intrusion of UCDW into the ML is studied in SODA by comparing the MLD and the top position of UCDW at each grid-point in a particular zone. If UCDW is detected closer to the surface than the MLD, this is recorded as UCDW having been detected in the ML. Data are presented in Figure 9 for the $60-65^{\circ} \mathrm{S}, 55-60^{\circ} \mathrm{S}$ and $50-55^{\circ} \mathrm{S}$ zones and these are broken down by decade and season, where the 2000-2005 data are scaled to 10 years. It is important to note that, although Figure 6 presents the seasonal cycles in both MLD and top UCDW, these data are climatological mean depths for the zone only and are misleading in the sense that they imply that UCDW is always at a lower depth than the MLD, which is not in fact the case.

Figure 9 shows noticeable differences between the three zones in terms of the seasons where the majority of detections of UCDW in the ML occur. In $60-65^{\circ} \mathrm{S}$ this happens in DJF and MAM, in $55-60^{\circ} \mathrm{S}$ in MAM, JJA and SON and in $50-55^{\circ} \mathrm{S}$ in JJA and SON. These figures are consistent with the theory that UCDW upwells south of the PF (around $55^{\circ} \mathrm{S}$ - see Figure 1), as well as entering the $55-60^{\circ} \mathrm{S}$ and $50-55^{\circ} \mathrm{S}$ zones from the south by Ekman transport. The seasonal difference may then be attributed to the time taken for UCDW to move northwards from the $60-65^{\circ} \mathrm{S}$ into the other two zones. For example, the time to move from $60-65^{\circ} \mathrm{S}$ to the $55-60^{\circ} \mathrm{S}$ zone is of the order of several months, based on moving $10^{\circ}$ north at the peak (March) northward Ekman velocity of $0.015 \mathrm{~ms}^{-1}$ (not presented) for the $60-65^{\circ} \mathrm{S}$ zone and this is consistent with the changes from Figure 9(a) to (b).

Even though the overall number of times UCDW is detected in the ML is greater in JJA than in any other season (overall totals for 50-65 ${ }^{\circ} \mathrm{S}$ are: DJF (132), MAM (243), JJA (370) and SON (306)), it would seem that UCDW is primarily entrained in the ML in summer/autumn (in 55-65 ${ }^{\circ} \mathrm{S}$ ), rather than in autumn/winter, as has previously been reported in the Atlantic (Hoppema et al., 2003; Gordon and Huber, 1990) and in the Pacific (Hiscock et al., 2003). The usual explanation involves the seasonal deepening of the ML but this does not seem to be the case, as both the MLD and the UCDW upwelling depth follow a similar seasonal cycle (see Figure 6), which means that the deepening of the ML in winter is accompanied by a concomitant deepening of the UCDW upwelling depth. 
Figure 9 also shows that the total number of times UCDW is detected in the ML has increased from the 1960s to the 2000s, including a large increase in the 1990s. This increasing trend is consistent with the trends found for the ML and UCDW - that is the ML is deepening (see Table 7) and UCDW is upwelling closer to the surface (see Table 4). Of note is the large number of detections in the 55$60^{\circ} \mathrm{S}$ zone (particularly in the 1990s, where UCDW is detected in the ML in 108 out of 120 possible months), the result of upwelling as well as advection.

\subsection{The connection with primary production in the southern-most zones}

UCDW upwells in the latitudinal zones $55-65^{\circ} \mathrm{S}$ and entrains nutrients that are essential for phytoplankton growth into the ML. This work has found that, for all seasons, there is a weak trend southwards in the southern-most latitude where UCDW can be detected. This may be important from the point of view of phytoplankton growth and biomass, due to the fact that, during the BROKE (Baseline Research on Oceanography Krill and the Environment) survey, a connection was found between circulation patterns (and surface water temperatures) and the abundance of krill compared with salps (Nicol et al., 2000).

The strongest trend associated with UCDW is associated with UCDW top depth; it is moving closer to the surface, which, combined with the deepening trend in the MLD, leads to an increase in the number of times UCDW is detected in the ML, again with implications for primary production. In addition, although an increasing trend in the upward Ekman pumping rate is found in summer (and autumn in $55-60^{\circ} \mathrm{S}$ ), this is not accompanied by an increase in the northward Ekman transport. This has the effect of increasing the time that the nutrients are available for primary production. Other significant summer trends in the $55-65^{\circ} \mathrm{S}$ zone are increasing wind stress (in $60-65^{\circ} \mathrm{S}$ ), increasing ML temperature and salinity (except in $60-65^{\circ} \mathrm{S}$ ) and increasing density. However, the relative impact of the various trends on PP is difficult to quantify and other factors, such as changes in irradiance levels, also need to be taken into account.

\subsection{Comparison of Results with Previous Studies}

Significant surface and subsurface warming in our sector of the Southern Ocean has been found both in a small number of regional observational studies (see below), as well as in the ensemble of coupled climate simulations, which were run as part of the IPCC Fourth Assessment Report (Trenberth et al., 2007). For example, Levitus et al. (2005) plotted vertical sections of the upper $1500 \mathrm{~m}$ in each of the Pacific, Indian and Atlantic oceans, showing trends in temperature from 1955-2003. These indicated increasing ML temperatures for most of the southern Pacific Ocean, excluding south of $70^{\circ}$ S. Global maps of SST trends from 1979-2005 (Trenberth et al., 2007) and some modelling studies (Zhang, 2007), indicate warming in the northern parts of the study region and possible cooling near the Antarctic continent, particularly in DJF, although sparse data coverage makes calculation of trends, in some southern parts of the region, difficult. Our results show an increase in ML temperature of around $1-2 \times 10^{-2}{ }^{\circ} \mathrm{C} / \mathrm{yr}$ (see Table 7), except in DJF and MAM in the most southerly $\left(60-65^{\circ} \mathrm{S}\right)$ zone, consistent with the above.

Data in our study region has been collected at Maria Island $\left(42.6^{\circ} \mathrm{S}, 148.23^{\circ} \mathrm{E}\right)$ from $1944-2005$, and recent work (Hill et al., 2008) has found a strong positive trend and quasi-decadal variability in both temperature and salinity $\left(2.2 \times 10^{-2}{ }^{\circ} \mathrm{C} / \mathrm{yr}\right.$ and $3 \times 10^{-3} /$ year, respectively). These are consistent in sign and order of magnitude with the ML results found here in that latitudinal region.

Similar vertical sections to those mentioned above for temperature have also been constructed for salinity (Boyer et al., 2005) and these show very different trends for salinity, depending on which ocean is being studied. For example, near-surface salinity increases are found over almost all of the Indian Ocean, whereas in the Pacific Ocean patches of decreasing trends are found, with the largest 
decreases south of $70^{\circ} \mathrm{S}$. This led to the IPCC conclusion (Trenberth et al., 2007) that in the polar region south of $50^{\circ} \mathrm{S}$ there is a relatively weak freshening signal. Decreasing salinity has been found at a few Southern Ocean sites near to Antarctica, possibly associated with increased precipitation, sea-ice extent, sea-ice melt or changes in CDW upwelling (Jacobs, 2006). Our study found increased ML salinity in all zones in the study region and this is consistent with trends of decreased precipitation north of $50^{\circ} \mathrm{S}$ and the results found at Maria Island, mentioned above. It is also consistent with the study by Curran et al. (2003), which found that sea-ice decreased in the East Antarctic region 80$140^{\circ} \mathrm{E}$ from the 1950 s to 1995 - decreasing sea-ice extent leads to decreasing ice melt and increasing salinity. It is unclear whether the ML trends found here for salinity south of $50^{\circ} \mathrm{S}$ are inconsistent with previous work, due to uncertainties introduced by the uneven spatial and temporal distribution of observations in this region (Jacobs, 2006; Boyer et al., 2005).

The few studies available have reported both surface and sub-surface warming in the SO. For example, a comparison of temperature data (Gille, 2002) from the 1950s and 1990s over the SO between 35 and $65^{\circ} \mathrm{S}$, in the 700-1100 $\mathrm{m}$ depth range, yields an increase of around $4 \times 10^{-3}{ }^{\circ} \mathrm{C} / \mathrm{yr}$, with warming concentrated within the ACC (Gille, 2008). This trend is similar to one found in the Indian sector of the SO (Aoki et al., 2003), close to the sACCf, taken as an average over 200-900 m for 1966-1998. Such results are similar to those found here for UCDW in the $60-65^{\circ} \mathrm{S}$ zone $\left(3.3 \times 10^{-3}\right.$ ${ }^{\circ} \mathrm{C} / \mathrm{yr}$ ), although our results do not find significant trends in the $55-60^{\circ} \mathrm{S}$ zone.

A recent study by Boning et al. (2008) has used both Argo float and historical data combined into a high resolution $\left(0.5^{\circ}\right)$ gridded climatology to examine temperature and salinity trends over the hemispheric SO. This data set does not resolve the seasonal cycle well and so no inferences are possible for the upper $200 \mathrm{~m}$. The study found temporal changes (1960-2006) across the ACC (SAF and PF), averaged over 300-1000 m, which showed temperature increases of $6 \times 10^{-3}{ }^{\circ} \mathrm{C} / \mathrm{yr}$ and salinity decreases of $-4 \times 10^{-4} /$ year. Our UCDW results for $60-65^{\circ} \mathrm{S}$ for temperature are in agreement with the other studies cited above (Aoki et al., 2003; Gille, 2002) and the above results in 60-65 $\mathrm{S}$, where UCDW lies in the depth range of the above results. Our results show an increasing trend in UCDW temperature only in $60-65^{\circ} \mathrm{S}$ and no significant trend in $50-55^{\circ} \mathrm{S}$, with decreasing UCDW temperature north of $55^{\circ} \mathrm{S}$. Our temperature results are, however, consistent with trends found from measurements taken in the Pacific along $170^{\circ} \mathrm{W}$ between 40 and $20^{\circ} \mathrm{S}$ from $1968 / 69$ to 1990 (Santoso et al., 2006; Johnson and Orsi, 1997), which show temperature trends of $-3 \times 10^{-3}{ }^{\circ} \mathrm{C} / \mathrm{yr}$ (and decreases in salinity) along deep density surfaces corresponding to UCDW. Boning et al. (2008) and Aoki et al. (2005) also studied UCDW on isopycnal surfaces, which are not directly comparable with this work, as the present results are obtained by averaging over the full UCDW density range ( $27.35 \mathrm{~kg}$ $\mathrm{m}^{-3}<\sigma_{\theta}<27.75 \mathrm{~kg} \mathrm{~m}^{-3}$ ) for $\theta>1.5^{\circ} \mathrm{C}$.

A recent study by Yang et al. (2007) has used an earlier version (1.4.2) of the SODA data that is used here to calculate trends associated with the meridional circulation, but in their case the trends are found for the whole SO. The authors found a strengthening of the Deacon cell, from 1980-2000, including an increase in the Ekman pumping rate and the northward Ekman velocity (which also showed a poleward shift), induced by changes in the SAM. However, recently (Boning et al., 2008) have concluded that the SO overturning circulation is insensitive to decadal changes in wind stress, due to stronger westerly winds inducing an increase in eddy activity, which counteracts increases in northward Ekman transport. Our study, which focuses on the region south of Australia and considers a longer time period (1958-2005) than the other SODA study, finds a complex response to wind forcing, which involves both SAM and ENSO, and, while it does find an increase in Ekman pumping, in certain seasons, south of $55^{\circ} \mathrm{S}$, does not find that this translates into an increase in northward Ekman transport in our region.

The work in this paper is based on the SODA 2.0.2/2.0.3 reanalysis dataset, which constrains POP model output using a wide selection of SO observational data. There are, however, limitations associated with this approach in the data-sparse SO, particularly in earlier time periods and in the deep 
ocean. This means that trends calculated for hydrographic variables in the deep ocean (for example, UCDW in low latitudes, but not UCDW where it is shoaling) need to be viewed with some caution. Hence, discrepancies between trends found here and those of other studies may possibly be related to the SODA data or they may be due to the fact that the $110^{\circ} \mathrm{E}-160^{\circ} \mathrm{E}$ region has its own idiosyncrasies associated with the effect of the SAM there. For example, the response of the oceanic fronts to the SAM varies in different regions of the SO, which the authors (Sallee et al., 2008) identify as the Indian, Central Pacific and Indo-Pacific basins. Thus comparison of trends, found using data from different regions, may not be valid. In addition, in the Australian region, the positive trend in the SAM is not accompanied by a southward shifting of the winds (consistent with our finding of no significant trend in the position of the maximum wind stress), unlike some other regions, such as the Indian basin (Drost and England, 2009).

It is worth noting here that recent work by Hosoda et al. (2009) and Roemmich and Gilson (2009), based on Argo float data, which shows decreasing surface layer salinity and temperature in some parts of the Australian sector, cannot be meaningfully compared with the present work, due to the time periods being considered. The trends presented here are over the time period 1958-2005, whereas the other studies compare mean values for 2003-2007 or 2004-2008, respectively, with climatological values from the World Ocean Database (1960-1989) or the World Ocean Atlas, respectively.

\section{Conclusions}

The work in this paper has focussed on the Australian region of the Southern Ocean $\left(110-160^{\circ} \mathrm{E}, 40\right.$ $65^{\circ} \mathrm{S}$ ) and uses data from the SODA 2.0.2/2.0.3 reanalysis to investigate the climatological physical environment, as well as trends in the time series (1958-2005) of various physical parameters. Results are analysed by season and by 5-degree latitudinal zone. Trends, presented below, represent the range in seasonal values for the southern-most zones $55-65^{\circ} \mathrm{S}$.

Significant strong increases are found in ML depth (0.18-0.62 m/year) and ML temperature (0.58$1.8 \times 10^{-2}{ }^{\circ} \mathrm{C} / \mathrm{yr}$ ), with the notable exception of ML temperature in DJF and MAM in the most southerly zone $\left(60-65^{\circ} \mathrm{S}\right)$, where no significant trends are found. Density stratification, found at the base of the ML, shows a decreasing trend over time, in some seasons, but not in DJF. Smaller increases are found

in ML density (0.9-2.1 $\times 10^{-3} \mathrm{~kg} \mathrm{~m}^{-3} /$ year) and salinity (1.3-3.2 $\times 10^{-3} /$ year). It should be noted that these trends are for the period 1958-2005 and cannot be compared with recent results, which show decreases in sea-surface temperature (Roemmich and Gilson, 2009) and salinity (Roemmich and Gilson, 2009; Hosoda et al., 2009), in some parts of the study region. This is due to the fact that these studies compare more recent Argo data with World Ocean Atlas climatological means, which results in a later and shorter time period being compared.

The above trends can be attributed, at least in part, to changes in the winds in the region, which show increasing strength in DJF, in line with positive trends in the SAM, with the strongest percentage increases occurring in DJF in $60-65^{\circ} \mathrm{S}$. Strong positive correlations, found between mean wind stress and ML depth (in all zones) and with ML density and salinity (south of $50^{\circ} \mathrm{S}$ ), particularly in DJF/MAM, are consistent with increasing ML depth and increasing ML density and salinity, due to increased wind mixing and evaporation. The seemingly anomalous result of no significant temperature trend in $60-65^{\circ} \mathrm{S}$ in DJF, as opposed to increasing ML temperature in all other zones and seasons, could also be related to wind mixing, where the increasing wind mixes cooler remnant winter water into the ML, counteracting the effect of surface warming.

Ekman pumping is found to increase in DJF/MAM in the southerly zones, but this does not lead to an increase in northward Ekman transport, nor does it seem to be connected to the depth to which UCDW upwells (at least on a decadal time-scale). Trends in UCDW upwelling are studied, as it is thought to be crucial in the supply of nutrients in the zones where it upwells (approximately $55-65^{\circ} \mathrm{S}$ ). 
The strongest (percentage) trend among the UCDW variables in the $55-65^{\circ} \mathrm{S}$ zones, is in UCDW top depth, indicating that UCDW is found to upwell closer to the surface over time (0.44 to 1.5 $\mathrm{m}$ /year). This leads to an increasing trend in the number of occasions where UCDW is found above the ML depth. Contrary to previous studies in other SO regions (Hiscock et al., 2003; Hoppema et al., 2003; Gordon and Huber, 1990), it appears that the main entrainment of UCDW into the ML in the Australian region occurs in summer/autumn, rather than autumn/winter. This is due to UCDW upwelling into the ML in $60-65^{\circ} \mathrm{S}$, predominantly in summer and autumn, and then moving northward over a period of months, where it can be detected in the ML in greater numbers in winter and spring.

Other significant UCDW trends include an increase in upwelling velocity (but predominantly in the more northerly zones, where UCDW is found at depths up to $2400 \mathrm{~m}$ ) and a decrease in UCDW temperature there, contrary to general upper ocean warming. An increase in UCDW temperature and a decrease in UCDW density and salinity are also found in the most southerly $60-65^{\circ} \mathrm{S}$ zone. In addition, a small but significant increase (southerly movement) in the latitude of the southernmost location of UCDW is also found. It would seem that trends in UCDW, except perhaps in the zones where it upwells and mixes with other water masses, occur on a different, and presumably much longer, timescale than changes in the ML.

In terms of the way the various physical features and trends are related to primary production in the most southerly zones of $55-65^{\circ} \mathrm{S}$ in the Australian region studied, it is found that, in this region, summer brings very shallow mixed layers and higher temperatures, very low wind stress, quite high stratification and very low northward Ekman velocities, which means that nutrients, injected into the ML by UCDW upwelling, will be advected northwards only slowly. The combination of these factors leads to favourable conditions for primary production, as does the increasing trend in the number of times UCDW can be detected in the ML. However, other trends documented here, such as increased ML depth with no increase in ML temperature or stratification in DJF, in addition to the southward trend in the position of UCDW upwelling, may counteract these effects.

\section{Acknowledgments}

This work was supported by Australian Antarctic Division grant, AAS Project 2784. Support from the Australian Research Network for Earth System Science (ARCNESS) is also gratefully acknowledged. The authors would also like to thank M. H. England for helpful discussions relating to this work. SO Front data was obtained from the Australian Antarctic Data Centre (IDN Node AMD/AU), a part of the Australian Antarctic Division (Commonwealth of Australia). These data are described in the metadata record 'Locations of the various fronts in the Southern Ocean' Orsi, A. and Ryan, U. (2001, updated 2006). The authors wish to acknowledge the use of the Ferret program for analysis and graphics in this study. Ferret is a product of NOAA's Pacific Marine Environmental Laboratory. MEI data was obtained from http://www.esrl.noaa.gov/psd/people/klaus.wolter/MEI/table.htm, SODA data was obtained from http://dsrs.atmos.umd.edu/DATA and SAM data from www.nercbas.ac.uk/icd/gjma/sam.html. 


\section{References}

Aoki, S., Bindoff, N. L. and Church, J. A. 2005. Interdecadal water mass changes in the Southern Ocean between 30 degrees E and 160 degrees E. Geophys. Res. Lett. 32(7), L07607.

Aoki, S., Yoritaka, M. and Masuyama, A. 2003. Mulidecadal warming of subsurface temperature in the Indian sector of the Southern Ocean. J. Geophys. Res. 108(C4), 8081.

Boning, C. W., Dispert, A., Visbeck, M., Rintoul, S. R. and Schwarzkopf, F. U. 2008. The response of the Antarctic Circumpolar Current to recent climate change. Nat. Geosci. 1(12), 864-869.

Boyer, T. P., Levitus, S., Antonov, J. I., Locarnini, R. and Garcia, H. E. 2005. Linear trends in salinity for the World Ocean, 1955-1998. Geophys. Res. Lett. 32, L01604.

Callahan, J. E. 1972. The structure and circulation of Deep Water in the Antarctic. Deep-Sea Res. 19, 563-575.

Carton, J. A., Chepurin, G., Cao, X. H. and Giese, B. 2000. A Simple Ocean Data Assimilation analysis of the global upper ocean 1950-95. Part I: Methodology. J. Phys. Oceanogr. 30(2), 294309.

Carton, J. A. and Giese, B. S. 2008. A reanalysis of ocean climate using SODA. Mon. Wea. Rev. 136(8), 2999-3017.

Carton, J. A., Giese, B. S. and Grodsky, S. A. 2005. Sea level rise and the warming of the oceans in the Simple Ocean Data Assimilation (SODA) ocean reanalysis. J. Geophys. Res.-Oceans 110(C9), C09006.

Curran, M. A. J., van Ommen, T. D., Morgan, V. I., Phillips, K. L. and Palmer, A. S. 2003. Ice core evidence for Antarctic sea ice decline since the 1950s. Science 302(5648), 1203-1206.

Drost, F. and England, M. H.: 2009, Spatial aspects of the Southern Annular Mode, Extremes: Climate and Water in the Southern Hemisphere, Vol. Short Abstracts, AMS/AMOS, p. 46.

Gilbert, R. O. 1987. Statistical methods for environmental pollution monitoring Gilbert, R. O. Van Nostrand Reinhold Company Inc., New York.

Gille, S. T. 2002. Warming of the Southern Ocean since the 1950s. Science 295(5558), 1275-1277.

Gille, S. T. 2008. Decadal-scale temperature trends in the Southern Hemisphere Ocean. J. Clim. 21(18), 4749-4765.

Gordon, A. L. 1967. Structure of Antarctic waters between 20W and 170W (ed. Bushnell, V. C.) Vol. 6 of Antarct. Map Folio Ser. Am. Geogr. Soc., New York.

Gordon, A. L. and Huber, B. A. 1990. Southern-Ocean winter mixed layer. J. Geophys. Res.-Oceans 95(C7), 11655-11672.

Hall, A. and Visbeck, M. 2002. Synchronous variability in the Southern Hemisphere atmosphere, sea ice, and ocean resulting from the Annular Mode. J. Clim. 15(21), 3043-3057.

Hess, A., Iyer, H. and Malm, W. 2001. Linear trend analysis: a comparison of methods. Atmos. Environ. 35(30), 5211-5222. 
Hill, K. L., Rintoul, S. R., Coleman, R. and Ridgway, K. R. 2008. Wind forced low frequency variability of the East Australia Current. Geophys. Res. Lett. 35(8), L08602.

Hirsch, R. M., Slack, J. R. and Smith, R. A. 1982. Techniques of trend analysis for monthly water quality data. Water Resour. Res. 18, 107-121.

Hiscock, M. R., Marra, J., Smith, W. O., Goericke, R., Measures, C., Vink, S., Olson, R. J., Sosik, H. M. and Barber, R. T. 2003. Primary productivity and its regulation in the Pacific Sector of the Southern Ocean. Deep-Sea Res. Part II-Top. Stud. Oceanogr. 50(3-4), 533-558.

Holbrook, N. J. and Bindoff, N. L. 1997. Interannual and decadal temperature variability in the southwest Pacific Ocean between 1955 and 1988. J. Clim. 10(5), 1035-1049.

Hoppema, M., de Baar, H. J. W., Fahrbach, E., Hellmer, H. H. and Klein, B. 2003. Substantial advective iron loss diminishes phytoplankton production in the Antarctic Zone. Glob. Biogeochem. Cycle 17(1), 1025.

Hosoda, S., Suga, T., Shikama, N. and Mizuno, K. 2009. Global surface layer salinity change detected by Argo and its implication for hydrological cycle intensification. J. Oceanogr. 65(4), 579-586.

Jacobs, S. 2006. Observations of change in the Southern Ocean. Philos. Trans. R. Soc. A-Math. Phys. Eng. Sci. 364(1844), 1657-1681.

Johnson, G. C. and Orsi, A. H. 1997. Southwest Pacific Ocean water-mass changes between 1968/69 and 1990/91. J. Clim. 10(2), 306-316.

Le Quere, C., Rödenbeck, C., Buitenhuis, E. T., Conway, T. J., Langenfelds, R., Gomez, A., Labuschagne, C., Ramonet, M., Nakazawa, T., Metzl, N., Gillett, N. and Heimann, M. 2007. Saturation of the Southern Ocean $\mathrm{CO}_{2}$ sink due to recent climate change. Science 316(5832), 17351738.

Lefebvre, W., Goosse, H., Timmermann, R. and Fichefet, T. 2004. Influence of the Southern Annular Mode on the sea ice-ocean system. J. Geophys. Res.-Oceans 109(C9), C09005.

Lenton, A. and Matear, R. J. 2007. Role of the Southern Annular Mode (SAM) in Southern Ocean $\mathrm{CO}_{2}$ uptake. Glob. Biogeochem. Cycle 21(2), GB2016.

Levitus, S., Antonov, J. and Boyer, T. 2005. Warming of the world ocean, 1955-2003. Geophys. Res. Lett. 32(2), L02604.

L'Heureux, M. L. and Thompson, D. W. J. 2006. Observed relationships between the El NinoSouthern Oscillation and the extratropical zonal-mean circulation. J. Clim. 19(2), 276-287.

Lovenduski, N. S. and Gruber, N. 2005. Impact of the Southern Annular Mode on Southern Ocean circulation and biology. Geophys. Res. Lett. 32(11), L11603.

Lovenduski, N. S., Gruber, N., Doney, S. C. and Lima, I. D. 2007. Enhanced CO2 outgassing in the Southern Ocean from a positive phase of the Southern Annular Mode. Glob. Biogeochem. Cycle 21(2), GB2026.

Marshall, G. J. 2003. Trends in the Southern Annular Mode from observations and reanalyses. $J$. Clim. 16(24), 4134-4143.

Marshall, G. J. 2007. Half-century seasonal relationships between the Southern Annular Mode and Antarctic temperatures. Int. J. Climatol. 27(3), 373-383. 
Martin, J. H., Gordon, R. M. and Fitzwater, S. E. 1990. Iron in Antarctic waters. Nature 345(6271), 156-158.

Montegut, C. D., Madec, G., Fischer, A. S., Lazar, A. and Iudicone, D. 2004. Mixed layer depth over the global ocean: An examination of profile data and a profile-based climatology. J. Geophys. Res.-Oceans 109(C12), C12003.

Monterey, G. and Levitus, S.: 1997, U.S. Government Printing Office, chapter Seasonal Variability of Mixed Layer Depth for the World Ocean, p. 96.

Nicol, S., Pauly, T., Bindoff, N. L., Wright, S., Thiele, D., Hosie, G. W., Strutton, P. G. and Woehler, E. 2000. Ocean circulation off east Antarctica affects ecosystem structure and sea-ice extent. Nature 406(6795), 504-507.

Orsi, A. H., Whitworth, T. and Nowlin, W. D. 1995. On the meridional extent and fronts of the Antarctic Circumpolar Current. Deep-Sea Res. Part I-Oceanogr. Res. Pap. 42(5), 641-673.

Orsi, A. and Ryan, U. 2001, updated 2006, Locations of the various fronts in the southern ocean, Australian Antarctic Data Centre - CAASM Metadata (http://data.aad.gov.au/aadc/metadata/).

Park, Y.-H., Gamberoni, L. and Charriaud, E. 1993. Frontal structure, water masses, and circulation in the Crozet Basin. J. Geophys. Res. 98(C7), 12361-12385.

Patterson, S. L. and Whitworth, T.: 1990, Elsevier, New York, chapter Physical Oceanography, pp. 55-93.

Roemmich, D. and Gilson, J. 2009. The 2004-2008 mean and annual cycle of temperature, salinity, and steric height in the global ocean from the Argo Program. Prog. Oceanogr. 82(2), 81-100.

Sallee, J. B., Speer, K. and Morrow, R. 2008. Response of the Antarctic Circumpolar Current to atmospheric variability. J. Clim. 21(12), 3020-3039.

Santoso, A., England, M. H. and Hirst, A. C. 2006. Circumpolar Deep Water circulation and variability in a coupled climate model. J. Phys. Oceanogr. 36(8), 1523-1552.

Schott, F. A., Stramma, L., Giese, B. S. and Zantopp, R. 2009. Labrador Sea convection and subpolar North Atlantic Deep Water export in the SODA assimilation model. Deep-Sea Res. Part I-Oceanogr. Res. Pap. 56(6), 926-938.

Schott, F. A., Stramma, L., Wang, W., Giese, B. S. and Zantopp, R. 2008. Pacific subtropical cell variability in the SODA 2.0.2/3 assimilation. Geophys. Res. Lett. 35, L10607.

Sievers, H. A. and Nowlin, W. D. 1984. The stratification and water masses at Drake Passage. $J$. Geophys. Res.-Oceans 89(NC6), 489-514.

Smith, R. D., Dukowicz, J. K. and Malone, R. C. 1992. Parallel ocean general circulation modeling. Physica D 60, 38-61.

Smith, R. and Gent, P.: May, 2002: revised May 2004, National Center for Atmospheric Research, Boulder, Colorado, USA.

Sokolov, S. 2008. Chlorophyll blooms in the Antarctic Zone south of Australia and New Zealand in reference to the Antarctic Circumpolar Current fronts and sea ice forcing. J. Geophys. Res.-Oceans 113, $\mathrm{C} 03022$. 
Sokolov, S. and Rintoul, S. R. 2002. Structure of Southern Ocean fronts at 140 degrees E. J. Mar. Syst. 37(1-3), 151-184.

Sokolov, S. and Rintoul, S. R. 2007. On the relationship between fronts of the Antarctic Circumpolar Current and surface chlorophyll concentrations in the Southern Ocean. J. Geophys. Res.-Oceans 112(C7), C07030.

Speer, K., Rintoul, S. R. and Sloyan, B. 2000. The diabatic Deacon cell. J. Phys. Oceanogr. 30(12), 3212-3222.

Spencer, M. W., Wu, C. L. and Long, D. G. 2000. Improved resolution backscatter measurements with the SeaWinds pencil-beam scatterometer. IEEE Trans. Geosci. Remote Sens. 38, 89-104.

Thompson, D. W. J. and Solomon, S. 2002. Interpretation of recent Southern Hemisphere climate change. Science 296(5569), 895-899.

Trenberth, K., Jones, P., Ambenje, P., Bojariu, R., Easterling, D., Tank, A. K., Parker, D., Rahimzadeh, F., Renwick, J., Rusticucci, M., Soden, B. and Zhai, P. 2007. Climate change 2007: The Physical Science basis. Contribution of working group I to the Fourth Assessment Report of the Intergovernmental Panel on Climate Change (eds. Solomon, S., Qin, D., Manning, M., Chen, Z., Marquis, M., Averyt, K., M.Tignor and Miller, H.) Observations: Surface and Atmospheric Climate Change Cambridge University Press, Cambridge.

Uppala, S., Kållberg, P., Simmons, A., Andrae, U., da Costa Bechtold, V., Fiorino, M., Gibson, J., Haseler, J., Hernandez, A., Kelly, G., Li, X., Onogi, K., Saarinen, S., Sokka, N., Allan, R., Andersson, E., Arpe, K., Balmaseda, M., Beljaars, A., van de Berg, L., Bidlot, J., Bormann, N., Caires, S., Chevallier, F., Dethof, A., Dragosavac, M., Fisher, M., Fuentes, M., Hagemann, S., Holm, E., Hoskins, B., Isaksen, L., Janssen, P., Jenne, R., McNally, A., Mahfouf, J.-F., Morcrette, J.-J., Rayner, N., Saunders, R., Simon, P., Sterl, A., Trenberth, K., Untch, A., Vasiljevic, D., Viterbo, P. and Woollen, J. 2005. The ERA-40 re-analysis. Quart. J. Roy. Meteor. Soc. 131, 2961-3012.

Visbeck, M. 2009. A station based Southern Annular Mode index from 1884-2005. J. Clim. 22(4), 940-950.

Wolter, K. 1987. The Southern Oscillation in surface circulation and climate over the tropical Atlantic, Eastern Pacific, and Indian Oceans as captured by cluster analysis. J. Climate Appl. Meteor. 26(4), 540-558.

Wolter, K. and Timlin, M. S.: 1993, Monitoring ENSO in COADS with a seasonally adjusted principal component index, Proc. of the 17th Climate Diagnostics Workshop, Oklahoma Clim. Survey, NOAA/N MC/CAC, CIMMS and the School of Meteor., Univ. of Oklahoma, pp. 52-57.

Yang, X.-Y., Dongxiao, D., Wang, J. and Huang, R. X. 2007. Connection between the decadal variabitity in the Southern Ocean circulation and the Southern Annular Mode. Geophys. Res. Lett. 34, L16604.

Zhang, J. 2007. Increasing Antarctic sea ice under warming atmospheric and oceanic conditions. $J$. Clim. 20(11), 2515-2529. 


\section{Figure Captions}

Figure 1: A plot from SODA showing sea surface temperature in January 2000 in the study area $110-160^{\circ} \mathrm{E}$ by $40-65^{\circ} \mathrm{S}$, overlaid by the Polar Front (PF) and the Southern Boundary (sBdy) of the ACC (Orsi and Ryan, 2001, updated 2006), between which UCDW upwells.

Figure 2: Isopycnals identifying UCDW are overlaid on a temperature plot along $140^{\circ} \mathrm{E}$ in February 1997. A temperature minimum layer (remnant winter water) can be seen above UCDW and below a shallow warm summer mixed layer.

Figure 3: Time series for SAM, mean wind stress and mixed layer depth, for the region $110-160^{\circ} \mathrm{E}$ by $55-60^{\circ} \mathrm{S}$ during summer (DJF).

Figure 4: Temperature distributions in November 2001 along $140^{\circ} \mathrm{E}$ from (a) Sokolov and Rintoul (2007) and (b) SODA. Note that the colour scales are different.

Figure 5: Salinity distributions in November 2001 along $140^{\circ}$ E from (a) Sokolov and Rintoul (2007) and (b) SODA. Note that the colour scales are different.

Figure 6: Climatologies of mixed layer depths and top UCDW depths for $60-65^{\circ} \mathrm{S}$ and $55-60^{\circ} \mathrm{S}$. Note that these are climatologies of median depths over a latitudinal zone and thus it cannot be concluded that UCDW is always at a lower depth than the mixed layer depth.

Figure 7: Climatology of maximum and mean wind stress, as well as location of maximum wind stress.

Figure 8: Climatology of density stratification (found at the base of the mixed layer) given by the Brunt-Vaissala Frequency squared.

Figure 9: Number of times UCDW is detected in the mixed layer by decade and season in (a) 60$65^{\circ} \mathrm{S}$, (b) $55-60^{\circ} \mathrm{S}$ and (c) $50-55^{\circ} \mathrm{S}$. Data from $2000-2005$ are scaled to 10 years. 


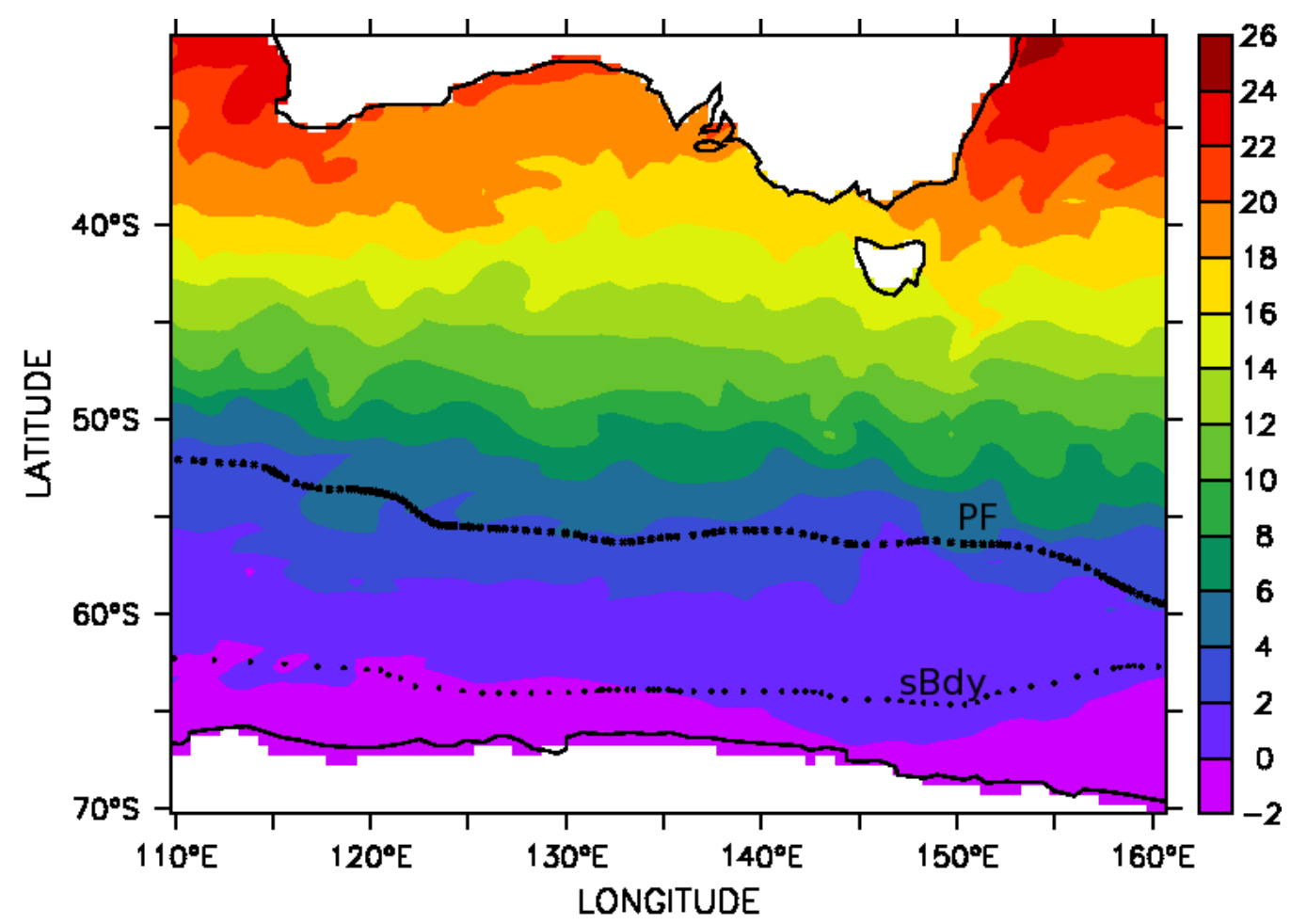

Figure 1: A plot from SODA showing sea surface temperature in January 2000 in the study area 110$160^{\circ} \mathrm{E}$ by $40-65^{\circ} \mathrm{S}$, overlaid by the Polar Front (PF) and the Southern Boundary (sBdy) of the ACC (Orsi and Ryan, 2001, updated 2006), between which UCDW upwells.

Table 1: Significant correlations between mean wind stress and either the SAM or MEI index (n/s=no significant correlation found). Correlations are found using detrended time series.

\begin{tabular}{|c|cc|cc|cc|cc|cc|}
\hline & \multicolumn{2}{|c|}{$60-65^{\circ} \mathrm{S}$} & \multicolumn{2}{c|}{$55-60^{\circ} \mathrm{S}$} & \multicolumn{2}{c|}{$50-55^{\circ} \mathrm{S}$} & \multicolumn{2}{c|}{$45-50^{\circ} \mathrm{S}$} & \multicolumn{2}{c|}{$40-45^{\circ} \mathrm{S}$} \\
\hline & SAM & MEI & SAM & MEI & SAM & MEI & SAM & MEI & SAM & MEI \\
\hline DJF & 0.53 & -0.34 & 0.80 & n/s & 0.49 & n/s & n/s & 0.37 & -0.37 & 0.43 \\
MAM & 0.54 & n/s & 0.70 & n/s & 0.52 & n/s & n/s & 0.37 & -0.31 & 0.33 \\
JJA & 0.47 & $\mathrm{n} / \mathrm{s}$ & 0.55 & $\mathrm{n} / \mathrm{s}$ & 0.52 & 0.41 & 0.49 & 0.52 & $\mathrm{n} / \mathrm{s}$ & 0.30 \\
SON & 0.56 & $\mathrm{n} / \mathrm{s}$ & 0.62 & $\mathrm{n} / \mathrm{s}$ & 0.41 & 0.43 & $\mathrm{n} / \mathrm{s}$ & 0.41 & -0.43 & $\mathrm{n} / \mathrm{s}$ \\
\hline
\end{tabular}




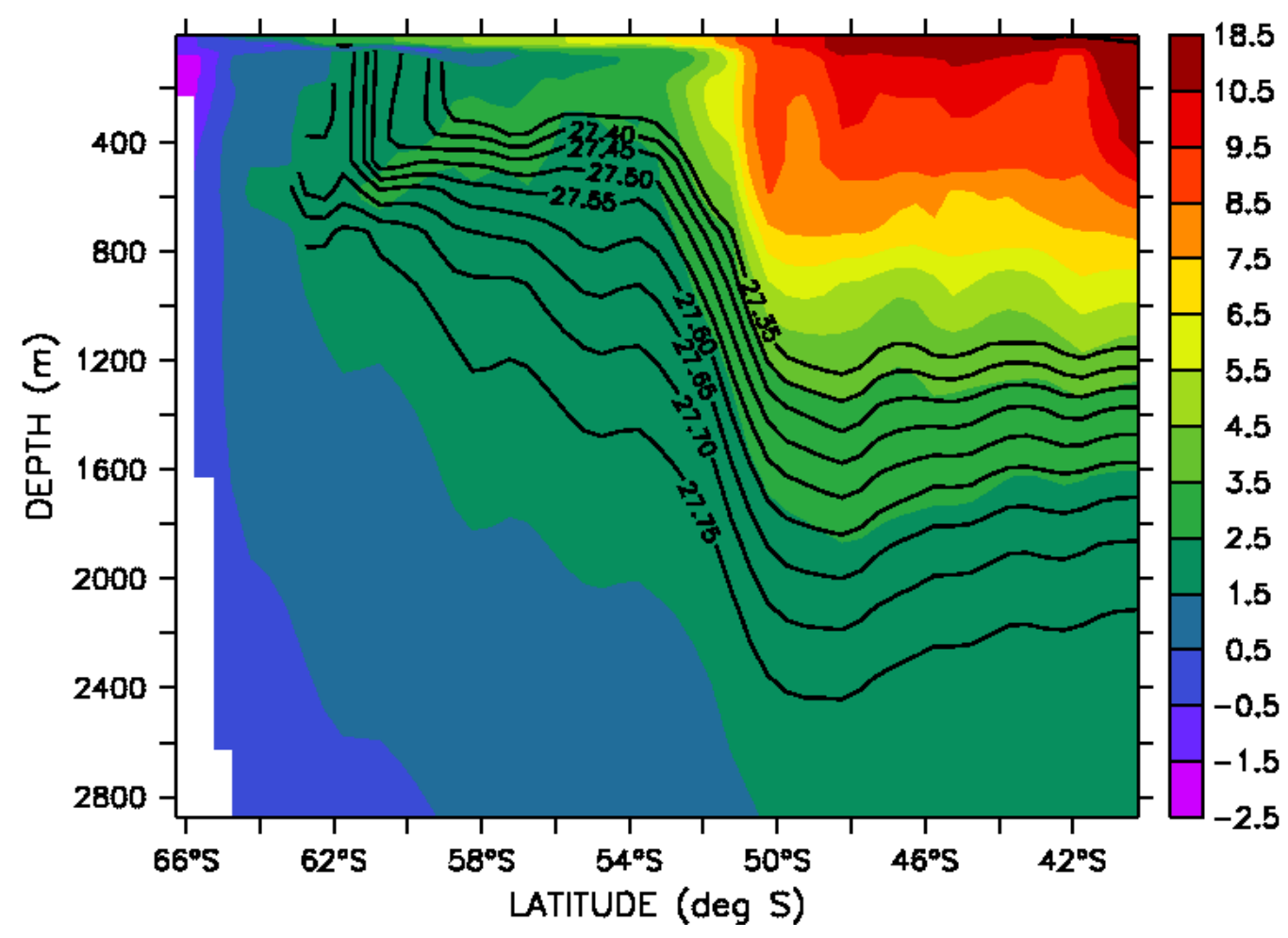

Figure 2: Isopycnals identifying UCDW are overlaid on a temperature plot along $140^{\circ} \mathrm{E}$ in February 1997. A temperature minimum layer (remnant winter water) can be seen above UCDW and below a shallow warm summer mixed layer. 

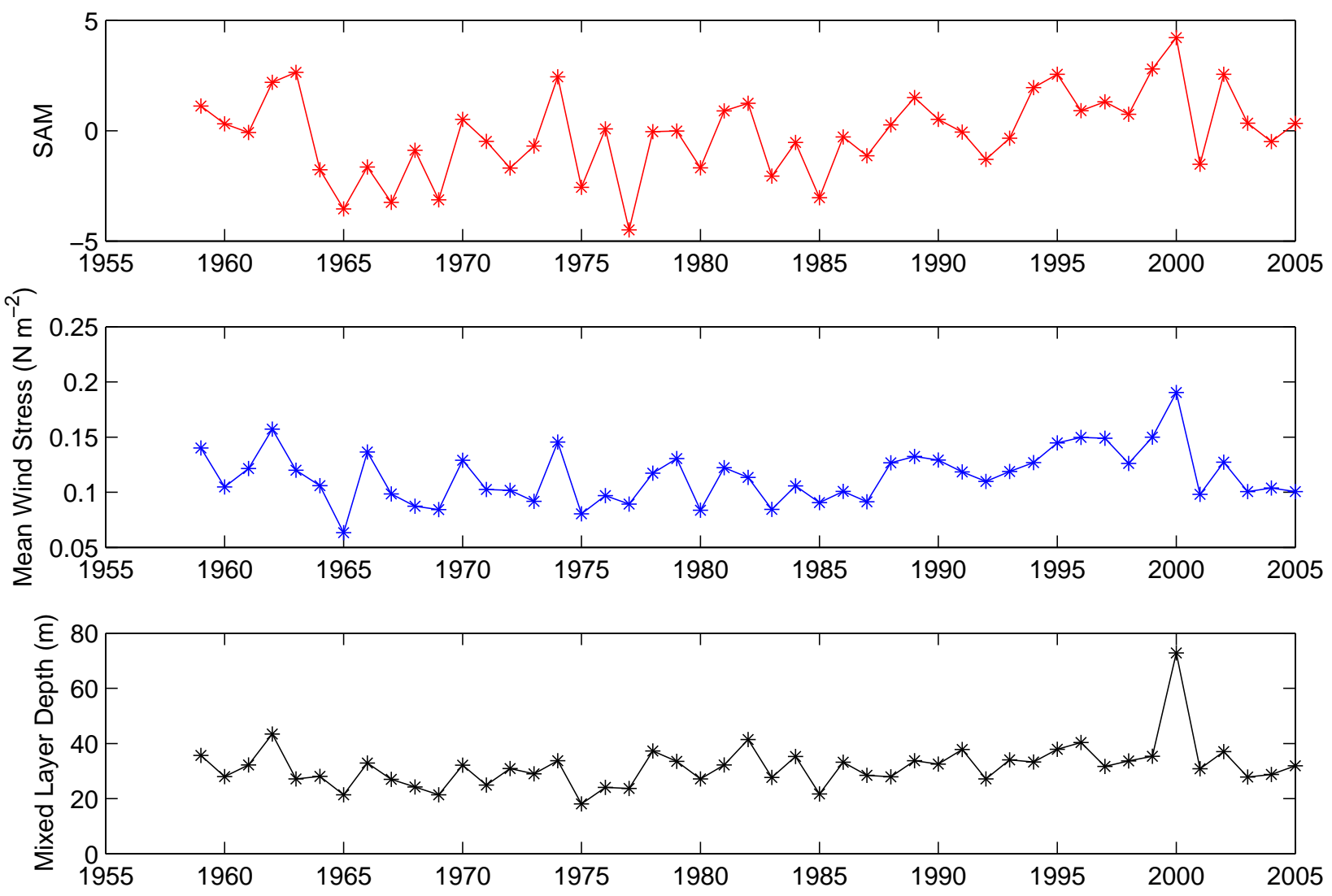

Figure 3: Time series for SAM, mean wind stress and mixed layer depth, for the region $110-160^{\circ} \mathrm{E}$ by $55-60^{\circ} \mathrm{S}$ during summer (DJF). 

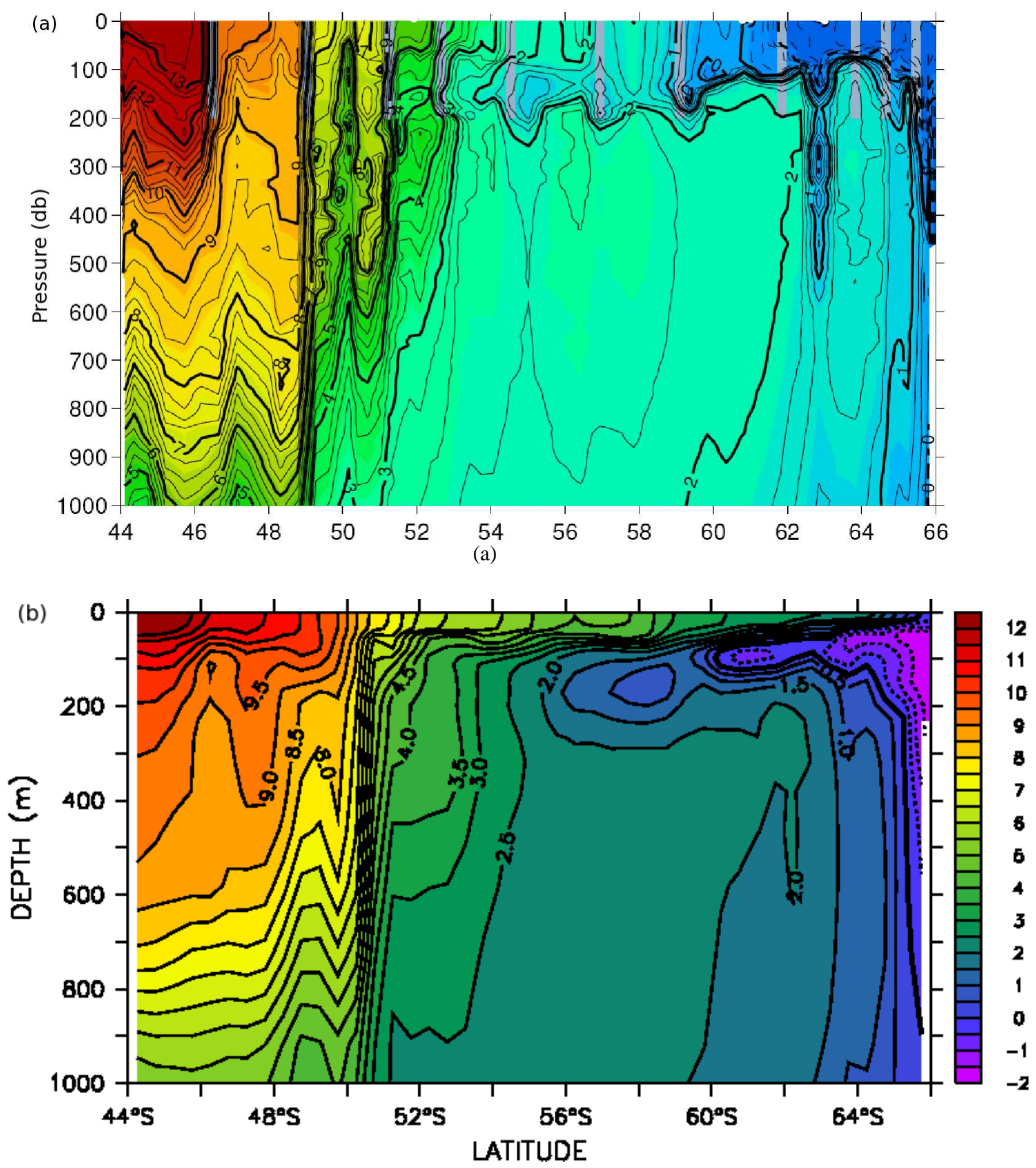

(b)

Figure 4: Temperature distributions in November 2001 along $140^{\circ} \mathrm{E}$ from (a) Sokolov and Rintoul (2007) and (b) SODA. Note that the colour scales are different. 


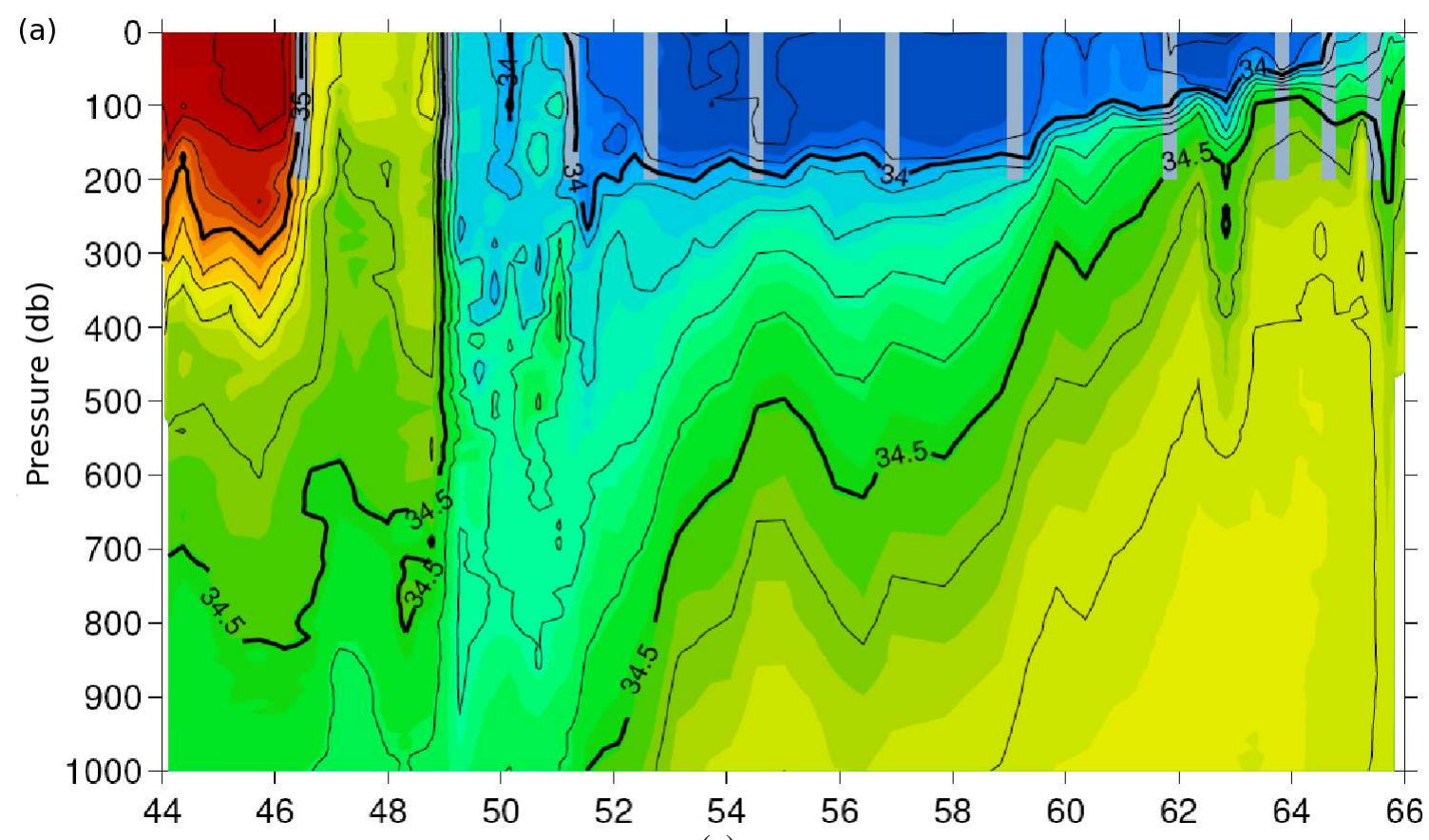

(a)

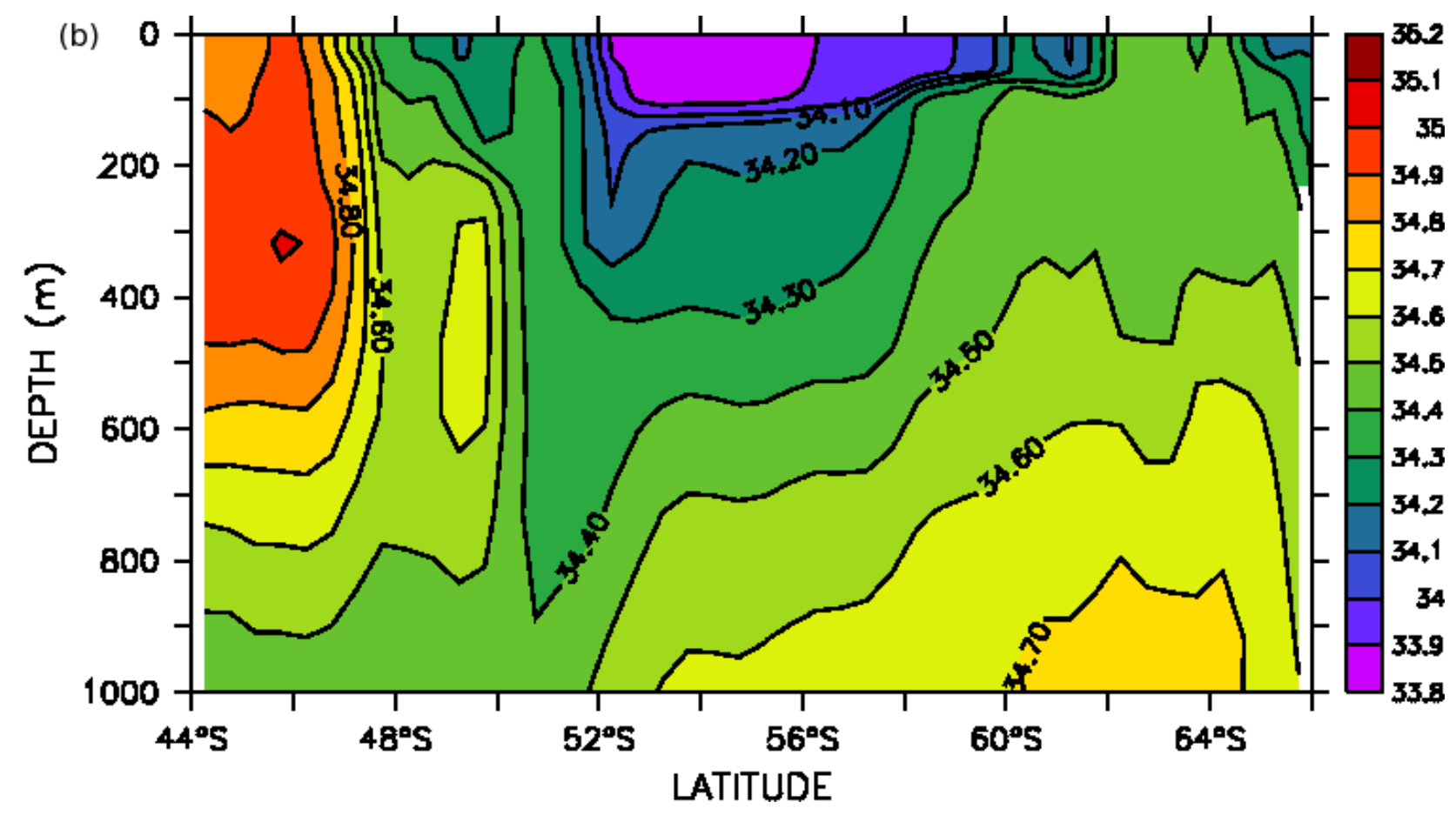

(b)

Figure 5: Salinity distributions in November 2001 along $140^{\circ}$ E from (a) Sokolov and Rintoul (2007) and (b) SODA. Note that the colour scales are different. 


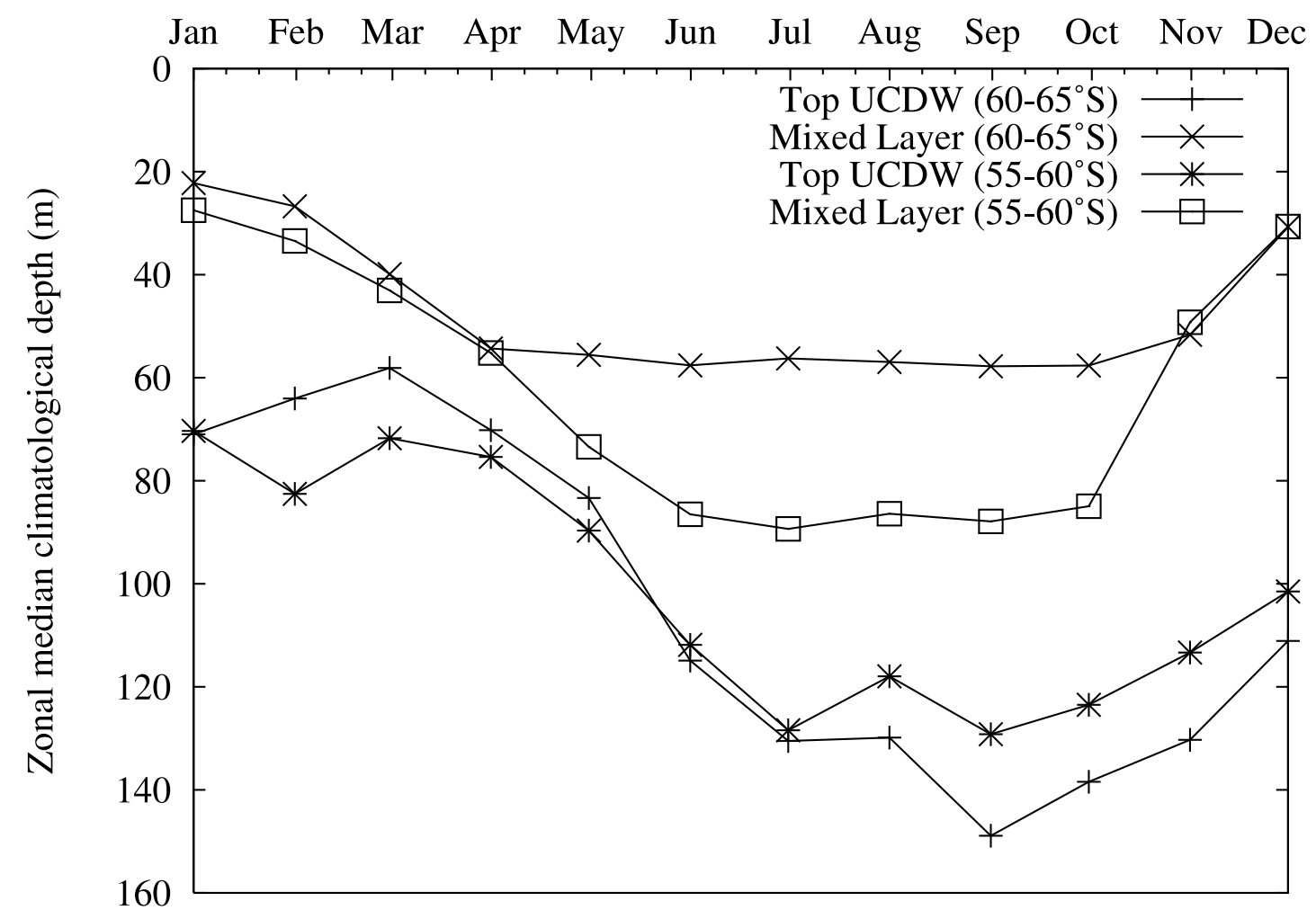

Figure 6: Climatologies of mixed layer depths and top UCDW depths for $60-65^{\circ} \mathrm{S}$ and $55-60^{\circ} \mathrm{S}$. Note that these are climatologies of median depths over a latitudinal zone and thus it cannot be concluded that UCDW is always at a lower depth than the mixed layer depth.

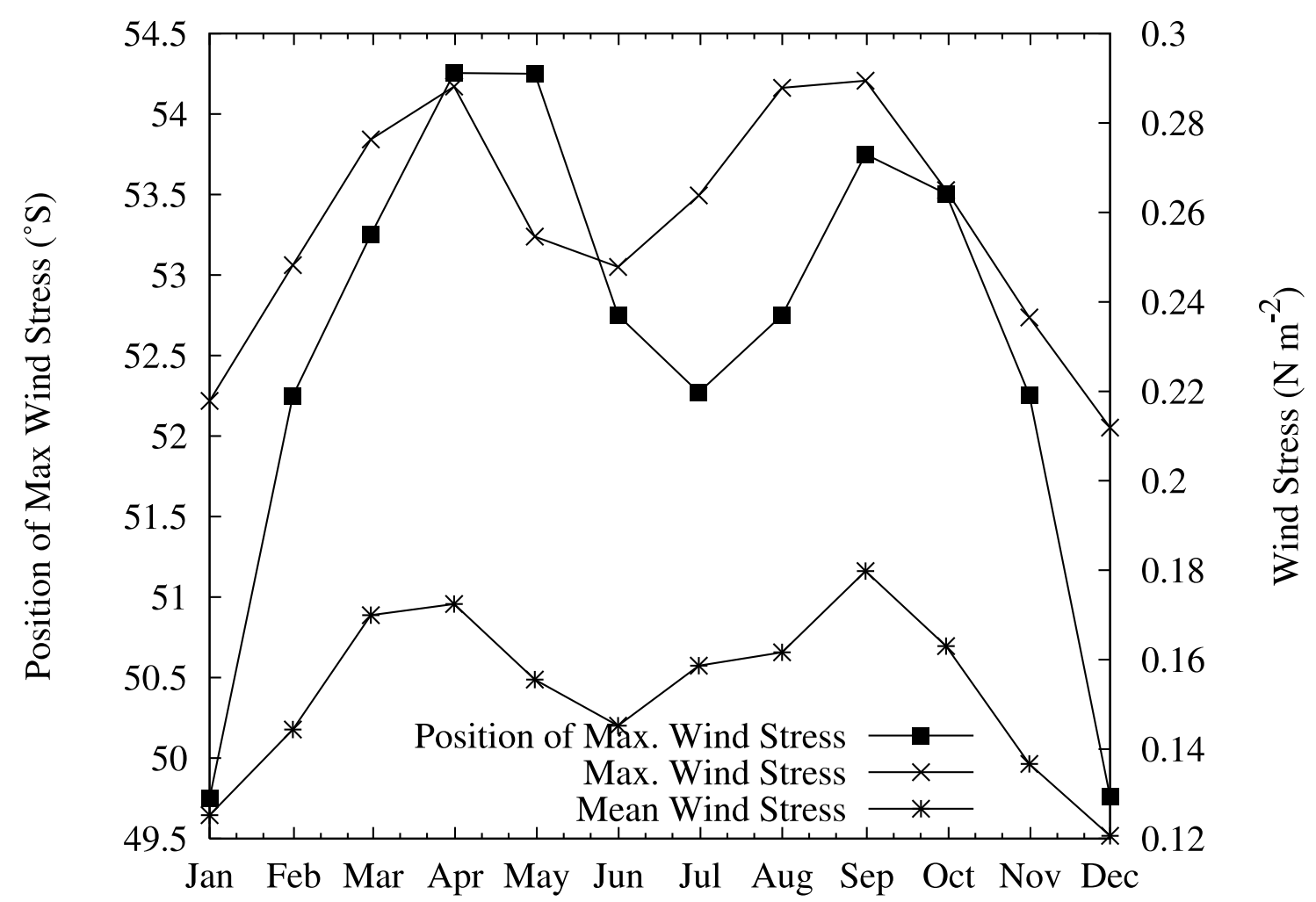

Figure 7: Climatology of maximum and mean wind stress, as well as location of maximum wind stress. 


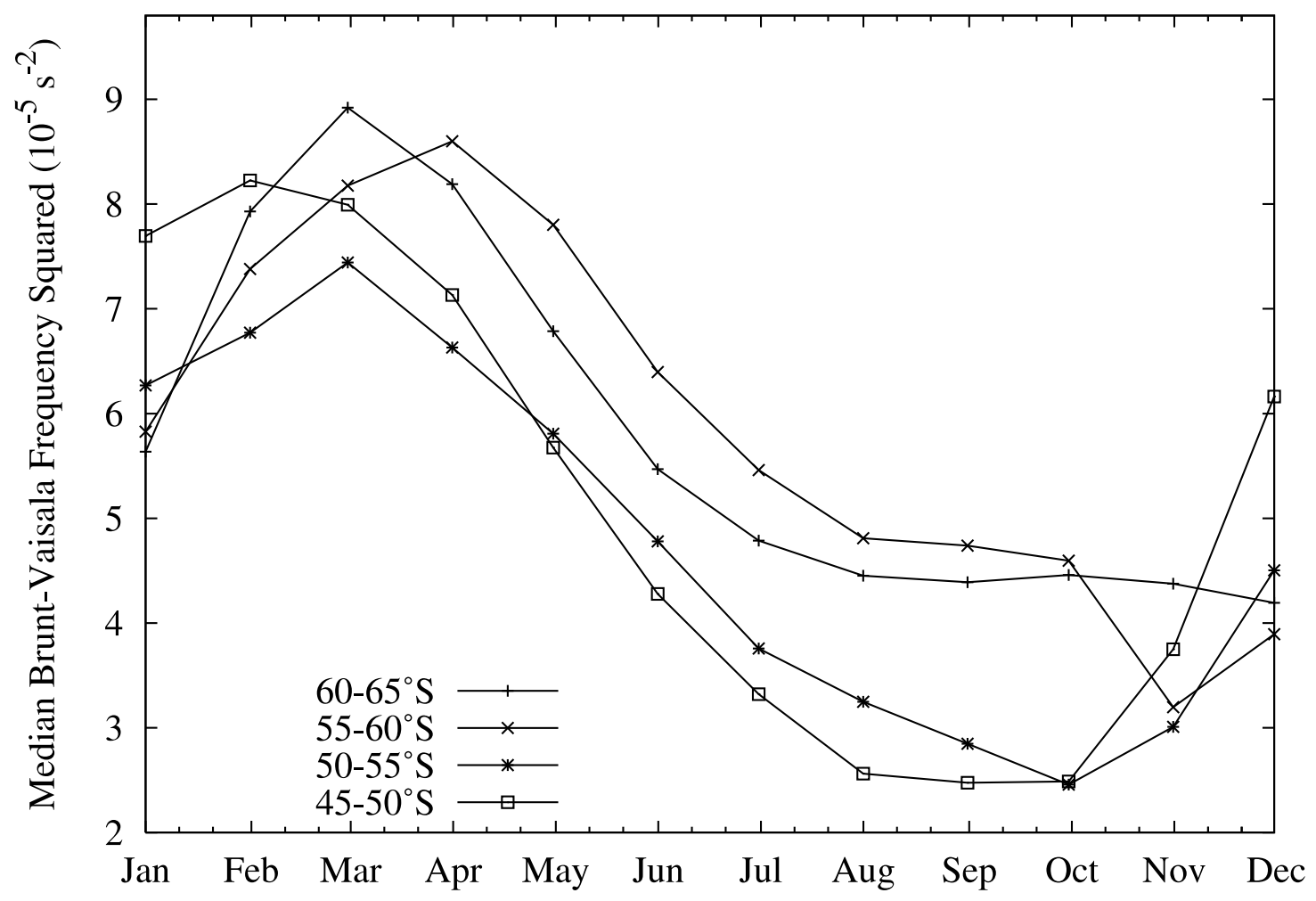

Figure 8: Climatology of density stratification (found at the base of the mixed layer) given by the Brunt-Vaissala Frequency squared. 


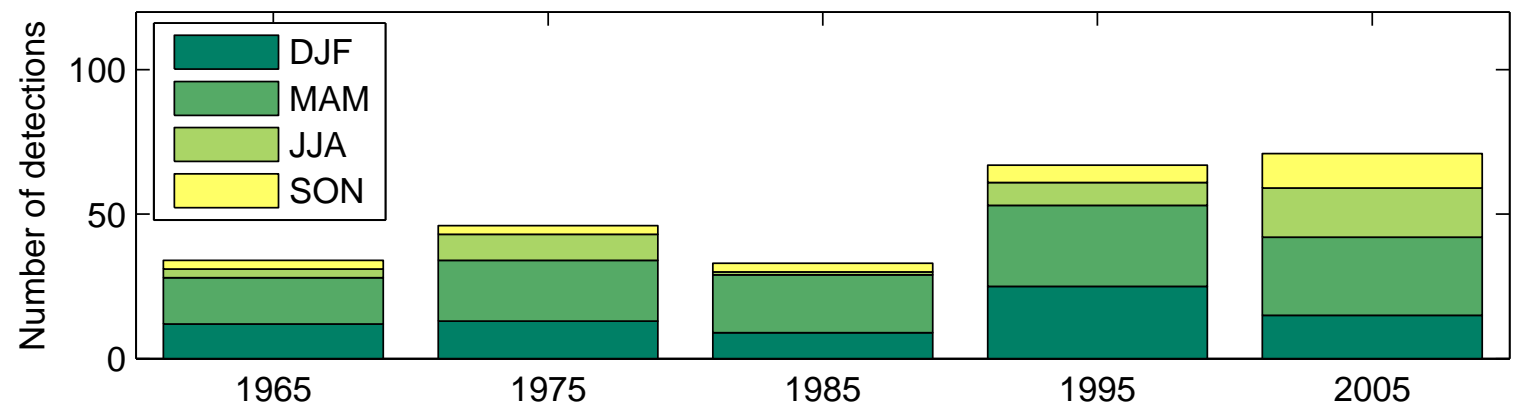

(a) $60-65^{\circ} \mathrm{S}$

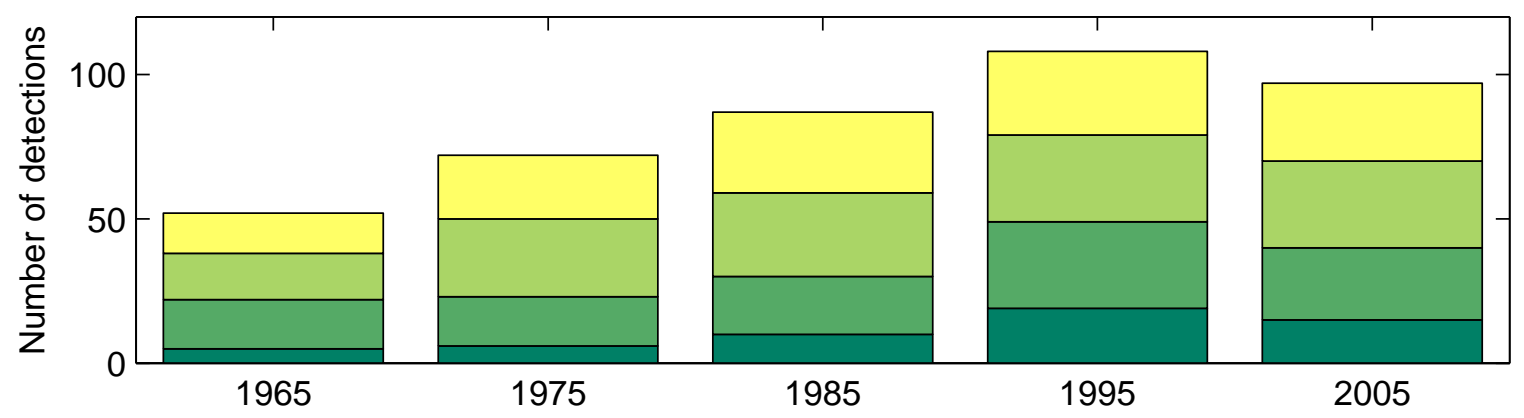

(b) $55-60^{\circ} \mathrm{S}$

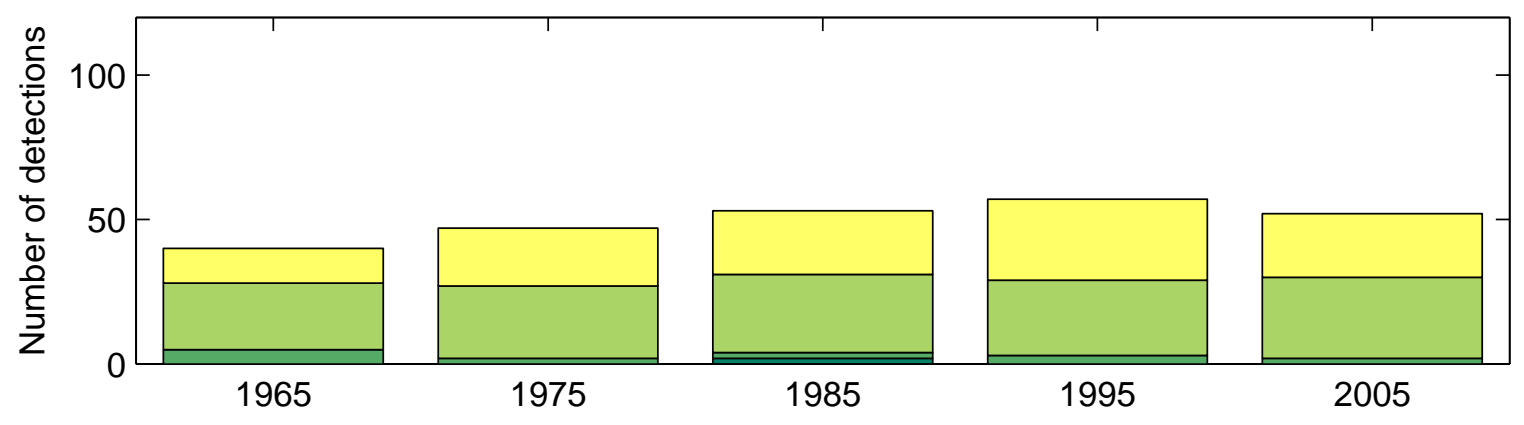

(b) $50-55^{\circ} \mathrm{S}$

Figure 9: Number of times UCDW is detected in the mixed layer by decade and season in (a) $60-65^{\circ} \mathrm{S}$, (b) $55-60^{\circ} \mathrm{S}$ and (c) $50-55^{\circ} \mathrm{S}$. Data from $2000-2005$ are scaled to 10 years. 
Table 2: Significant correlations (and when they occur) between the mean wind stress and the variables presented ( $\mathrm{n} / \mathrm{s}=$ no significant correlation found). Correlations are found using detrended time series.

\begin{tabular}{|c|c|c|c|c|c|}
\hline $\begin{array}{c}\text { Zone } \\
110-160^{\circ} \mathrm{E} \\
\text { by }\end{array}$ & $60-65^{\circ} \mathrm{S}$ & $55-60^{\circ} \mathrm{S}$ & $50-55^{\circ} \mathrm{S}$ & $45-50^{\circ} \mathrm{S}$ & $40-45^{\circ} \mathrm{S}$ \\
\hline $\begin{array}{c}\text { UCDW Vertical } \\
\text { Velocity }\end{array}$ & $\mathrm{n} / \mathrm{s}$ & $\mathrm{n} / \mathrm{s}$ & $\mathrm{n} / \mathrm{s}$ & $\mathrm{n} / \mathrm{s}$ & $\mathrm{n} / \mathrm{s}$ \\
\hline $\begin{array}{c}\text { UCDW } \\
\text { Temperature }\end{array}$ & $\mathrm{n} / \mathrm{s}$ & $\mathrm{n} / \mathrm{s}$ & $\mathrm{n} / \mathrm{s}$ & SON(0.36) & $\mathrm{DJF}(0.30)$ \\
\hline $\begin{array}{l}\text { UCDW } \\
\text { Density }\end{array}$ & $\mathrm{n} / \mathrm{s}$ & $\mathrm{n} / \mathrm{s}$ & $\mathrm{SON}(-0.30)$ & SON(-0.38) & $\mathrm{n} / \mathrm{s}$ \\
\hline $\begin{array}{l}\text { UCDW } \\
\text { Salinity }\end{array}$ & $\begin{array}{c}\operatorname{MAM}(0.32) \\
\mathrm{JJA}(0.31)\end{array}$ & $\mathrm{n} / \mathrm{s}$ & $\mathrm{SON}(-0.35)$ & $\mathrm{DJF}(0.30)$ & $\mathrm{SON}(0.30)$ \\
\hline $\begin{array}{l}\text { UCDW } \\
\text { Top Depth }\end{array}$ & $\mathrm{n} / \mathrm{s}$ & $\mathrm{n} / \mathrm{s}$ & $\mathrm{n} / \mathrm{s}$ & $\mathrm{n} / \mathrm{s}$ & $\mathrm{n} / \mathrm{s}$ \\
\hline ML Depth & $\begin{array}{l}\operatorname{DJF}(0.42) \\
\operatorname{SON}(0.30)\end{array}$ & $\begin{array}{c}\operatorname{DJF}(0.78) \\
\operatorname{MAM}(0.36) \\
\operatorname{SON}(0.44)\end{array}$ & $\overline{\mathrm{DJF}}(0.69)$ & $\mathrm{DJF}(0.54)$ & $\begin{array}{c}\operatorname{DJF}(0.80) \\
\operatorname{MAM}(0.45) \\
\operatorname{SON}(0.34)\end{array}$ \\
\hline $\begin{array}{c}\text { ML } \\
\text { Temperature }\end{array}$ & DJF(-0.43) & $\begin{array}{c}\text { DJF(-0.59) } \\
\operatorname{MAM}(-0.38)\end{array}$ & $\begin{array}{c}\text { DJF(-0.53) } \\
\operatorname{MAM}(-0.35)\end{array}$ & $\begin{array}{c}\mathrm{DJF}(-0.40) \\
\operatorname{MAM}(-0.33)\end{array}$ & $\begin{array}{c}\mathrm{DJF}(-0.52) \\
\operatorname{MAM}(-0.59)\end{array}$ \\
\hline ML Density & $\begin{array}{l}\text { DJF(0.55) } \\
\\
\text { JJA }(0.37) \\
\text { SON(0.34) }\end{array}$ & $\begin{array}{c}\mathrm{DJF}(0.54) \\
\operatorname{MAM}(0.31) \\
\mathrm{JJA}(0.30) \\
\operatorname{SON}(0.32)\end{array}$ & $\mathrm{DJF}(0.31)$ & $\mathrm{n} / \mathrm{s}$ & $\begin{array}{c}\operatorname{DJF}(0.38) \\
\operatorname{MAM}(0.34)\end{array}$ \\
\hline ML Salinity & $\begin{array}{c}\mathrm{DJF}(0.50) \\
\mathrm{JJA}(0.37) \\
\mathrm{SON}(0.32)\end{array}$ & $\mathrm{DJF}(0.34)$ & $\mathrm{n} / \mathrm{s}$ & $\mathrm{n} / \mathrm{s}$ & $\mathrm{n} / \mathrm{s}$ \\
\hline Stratification & $\mathrm{n} / \mathrm{s}$ & $\begin{array}{l}\text { DJF(-0.41) } \\
\text { SON(0.31) }\end{array}$ & DJF(-0.38) & $\mathrm{n} / \mathrm{s}$ & $\mathrm{n} / \mathrm{s}$ \\
\hline $\begin{array}{l}\text { Upward Ekman } \\
\text { Pumping Rate }\end{array}$ & $\begin{array}{c}\operatorname{DJF}(0.51) \\
\operatorname{MAM}(0.74) \\
\text { JJA(0.67) } \\
\text { SON(0.67) }\end{array}$ & $\mathrm{n} / \mathrm{s}$ & $\mathrm{n} / \mathrm{a}$ & $\mathrm{n} / \mathrm{a}$ & $\mathrm{n} / \mathrm{a}$ \\
\hline
\end{tabular}

Table 3: Means of climatological values for UCDW variables.

\begin{tabular}{|cccccc|}
\hline $\begin{array}{c}\text { Zone } \\
110-160^{\circ} \mathrm{E} \\
\text { by }\left({ }^{\circ} \mathrm{S}\right)\end{array}$ & $\begin{array}{c}\text { Mean } \\
\text { Vertical } \\
\text { Velocity } \\
\left(\mathrm{m} \mathrm{s}^{-1}\right)\end{array}$ & $\begin{array}{c}\text { Mean } \\
\text { Temperature }\end{array}$ & $\begin{array}{c}\text { Mean } \\
\text { Density }\end{array}$ & $\begin{array}{c}\text { Mean } \\
\text { Salinity }\end{array}$ & $\begin{array}{c}\text { Mean } \\
\text { Depth } \\
\text { Range } \\
(\mathrm{m})\end{array}$ \\
\hline $60-65$ & $3.2 \times 10^{-6}$ & 1.9 & 27.7 & 34.6 & $90-900$ \\
$55-60$ & $1.9 \times 10^{-5}$ & 2.1 & 27.6 & 34.6 & $90-1600$ \\
$50-55$ & $2.3 \times 10^{-5}$ & 2.4 & 27.6 & 34.6 & $130-2400$ \\
$45-50$ & $9.2 \times 10^{-6}$ & 2.6 & 27.6 & 34.6 & $400-2400$ \\
$40-45$ & $3.3 \times 10^{-6}$ & 2.7 & 27.6 & 34.6 & $1100-2400$ \\
\hline
\end{tabular}


Table 4: Significant maximum trends (per year) for UCDW variables (n/s=no significant trend, + indicates increasing trend (eg. UCDW is upwelling closer to the surface and further south), * indicates season in which maximum trend occurs).

\begin{tabular}{|c|c|c|c|c|c|}
\hline $\begin{array}{c}\text { Zone } \\
110-160^{\circ} \mathrm{E} \\
\text { by }\left({ }^{\circ} \mathrm{S}\right)\end{array}$ & $\begin{array}{c}\Delta \text { Mean } \\
\text { Vertical } \\
\text { Velocity } \\
\left(\mathrm{m} \mathrm{s}^{-1} \mathrm{yr}^{-1}\right)\end{array}$ & $\begin{array}{c}\Delta \text { Mean } \\
\text { Temperature } \\
\left({ }^{\circ} \mathrm{C} \mathrm{yr}^{-1}\right)\end{array}$ & $\begin{array}{c}\Delta \text { Mean } \\
\text { Density } \\
\left(\mathrm{kg} \mathrm{m}^{-3} \mathrm{yr}^{-1}\right)\end{array}$ & $\begin{array}{c}\Delta \text { Mean } \\
\text { Salinity } \\
\left(\mathrm{yr}^{-1}\right)\end{array}$ & $\begin{array}{c}\Delta \text { Mean } \\
\text { Top Depth } \\
\left(\mathrm{m} \mathrm{yr}^{-1}\right)\end{array}$ \\
\hline $60-65$ & $\begin{array}{l}1.7 \times 10^{-8} \\
\text { MAM* }^{*}\end{array}$ & $\begin{array}{c}3.3 \times 10^{-3} \\
\text { ALL(MAM*) }\end{array}$ & $\begin{array}{c}-4.5 \times 10^{-4} \\
\operatorname{ALL}\left(\mathrm{SON}^{*}\right)\end{array}$ & $\begin{array}{l}-4.2 \times 10^{-4} \\
\text { JJA,SON* }\end{array}$ & $\begin{array}{c}1.0 \\
\text { ALL(DJF*) }\end{array}$ \\
\hline $55-60$ & $\begin{array}{c}-6.6 \times 10^{-8} \\
\mathrm{SON}^{*}\end{array}$ & $\mathrm{n} / \mathrm{s}$ & $\mathrm{n} / \mathrm{s}$ & $\mathrm{n} / \mathrm{s}$ & $\begin{array}{c}1.5 \\
\mathrm{DJF}^{*}, \mathrm{MAM} \\
\mathrm{JJA}\end{array}$ \\
\hline $50-55$ & $\begin{array}{c}8.9 \times 10^{-8} \\
\text { ALL(DJF*) }\end{array}$ & $\begin{array}{c}-2.4 \times 10^{-3} \\
\operatorname{ALL}\left(\mathrm{SON}^{*}\right)\end{array}$ & $\mathrm{n} / \mathrm{s}$ & $\mathrm{n} / \mathrm{s}$ & $\begin{array}{c}0.44 \\
\text { MAM* }^{*}\end{array}$ \\
\hline $45-50$ & $\begin{array}{c}7.1 \times 10^{-8} \\
\operatorname{ALL}\left(\mathrm{MAM}^{*}\right)\end{array}$ & $\begin{array}{c}-1.5 \times 10^{-3} \\
\operatorname{ALL}\left(\mathrm{SON}^{*}\right)\end{array}$ & $\mathrm{n} / \mathrm{s}$ & $\mathrm{n} / \mathrm{s}$ & $\begin{array}{c}2.1 /-0.22 \\
\mathrm{DJF}^{*} / \mathrm{JJA}\end{array}$ \\
\hline $40-45$ & $\begin{array}{c}4.0 \times 10^{-8} \\
\text { ALL(DJF*) }\end{array}$ & $\begin{array}{l}-8.1 \times 10^{-4} \\
\operatorname{ALL}\left(J^{*} A^{*}\right)\end{array}$ & $\mathrm{n} / \mathrm{s}$ & $\mathrm{n} / \mathrm{s}$ & $\mathrm{n} / \mathrm{s}$ \\
\hline $\begin{array}{c}\triangle \mathrm{UCDW} \\
\text { Southerly } \\
\left.\text { Position ( }{ }^{\circ} \mathrm{S}\right)\end{array}$ & $\begin{array}{c}1.7 \times 10^{-2} \\
\operatorname{ALL}\left(J^{*} A^{*}\right)\end{array}$ & & & & \\
\hline
\end{tabular}


Table 5: Significant maximum trends (per year) for various other variables (n/s=no significant trend, $\mathrm{n} / \mathrm{a}=$ not applicable, + indicates increasing trend, * indicates season in which maximum trend occurs).

\begin{tabular}{|c|c|c|c|c|}
\hline $\begin{array}{c}\text { Zone } \\
110-160^{\circ} \mathrm{E} \\
\text { by }\left({ }^{\circ} \mathrm{S}\right)\end{array}$ & $\begin{array}{c}\Delta \text { Mean } \\
\text { Stratification } \\
\left(\mathrm{s}^{-2} \mathrm{yr}^{-1}\right) \\
\end{array}$ & $\begin{array}{c}\Delta \text { Mean } \\
\text { Wind Stress } \\
\left(\mathrm{Nm}^{-2} \mathrm{yr}^{-1}\right)\end{array}$ & $\begin{array}{c}\Delta \text { Mean } \\
\text { Upward Ekman } \\
\text { Pumping Rate } \\
\left(\mathrm{ms}^{-1} \mathrm{yr}^{-1}\right)\end{array}$ & $\begin{array}{c}\Delta \text { Mean } \\
\text { Northward } \\
\text { Ekman Transport } \\
\left(\mathrm{Sv} \mathrm{yr}{ }^{-1}\right)\end{array}$ \\
\hline $60-65$ & $\begin{array}{c}-2.0 \times 10^{-7} \\
\mathrm{MAM}^{*}, \mathrm{JJA} \\
\mathrm{SON}\end{array}$ & $\begin{array}{l}3.7 \times 10^{-4} \\
\text { DJF* }^{*}\end{array}$ & $\begin{array}{c}1.2 \times 10^{-8} /-9.2 \times 10^{-9} \\
\mathrm{DJF}^{*} / \mathrm{SON}\end{array}$ & $\mathrm{n} / \mathrm{s}$ \\
\hline $55-60$ & $\begin{array}{l}-1.9 \times 10^{-7} \\
\text { MAM* }^{*}\end{array}$ & $\mathrm{n} / \mathrm{s}$ & $\begin{array}{c}1.0 \times 10^{-8} \\
\mathrm{DJF}^{*}, \mathrm{MAM}\end{array}$ & $\begin{array}{l}-1.9 \times 10^{-2} \\
\mathrm{SON}^{*}\end{array}$ \\
\hline $50-55$ & $\begin{array}{l}-4.3 \times 10^{-7} \\
\text { DJF,MAM* } \\
\text { JJA }\end{array}$ & $\begin{array}{c}5.9 \times 10^{-4} \\
\mathrm{DJF}^{*}\end{array}$ & $\mathrm{n} / \mathrm{a}$ & $\begin{array}{l}1.6 /-1.8 \times 10^{-2} \\
\mathrm{DJF}^{*} / \mathrm{SON}^{*}\end{array}$ \\
\hline $45-50$ & $\begin{array}{c}-5.3 \times 10^{-7} \\
\text { DJF,MAM* } \\
\text { JJA }\end{array}$ & $\begin{array}{c}6.0 \times 10^{-4} \\
\text { DJF,MAM* } \\
\text { JJA }^{*}\end{array}$ & $\mathrm{n} / \mathrm{a}$ & $\begin{array}{l}2.4 \times 10^{-2} \\
\text { DJF,JJA* }\end{array}$ \\
\hline $40-45$ & $\begin{array}{l}-2.2 \times 10^{-7} \\
\text { SON }^{*}\end{array}$ & $\begin{array}{c}5.1 \times 10^{-4} \\
\text { DJF,MAM* } \\
\text { JJA }^{*}\end{array}$ & $\mathrm{n} / \mathrm{a}$ & $\begin{array}{l}2.2 \times 10^{-2} \\
\text { DJF,JJA* }\end{array}$ \\
\hline $\begin{array}{l}\text { Maximum } \\
\text { Wind } \\
\text { Stress }\end{array}$ & $\begin{array}{c}9.1 \times 10^{-4} \\
\text { DJF,MAM* }\end{array}$ & $\begin{array}{l}\text { Location of } \\
\text { Maximum } \\
\text { Wind Stress }\end{array}$ & $\mathrm{n} / \mathrm{s}$ & \\
\hline
\end{tabular}

Table 6: Means of climatological values for Mixed Layer variables.

\begin{tabular}{|c|c|c|c|c|c|c|c|c|}
\hline Zone & \multicolumn{2}{|c|}{ Mean Density } & \multicolumn{2}{|c|}{ Mean Salinity } & \multicolumn{2}{|c|}{ Mean Depth } & \multicolumn{2}{|c|}{ Mean Temperature } \\
\hline $\begin{array}{c}110-160^{\circ} \mathrm{E} \\
\text { by }\left({ }^{\circ} \mathrm{S}\right)\end{array}$ & $\begin{array}{l}\text { Summer } \\
\left(\mathrm{kg} \mathrm{m}^{-3}\right)\end{array}$ & $\begin{array}{c}\text { Winter } \\
\left(\mathrm{kg} \mathrm{m}^{-3}\right)\end{array}$ & Summer & Winter & $\begin{array}{c}\text { Summer } \\
\text { (m) }\end{array}$ & $\begin{array}{l}\text { Winter } \\
\text { (m) }\end{array}$ & $\begin{array}{c}\text { Summer } \\
\left({ }^{\circ} \mathrm{C}\right)\end{array}$ & $\begin{array}{c}\text { Winter } \\
\left({ }^{\circ} \mathrm{C}\right)\end{array}$ \\
\hline $60-65$ & 27.2 & 27.4 & 33.9 & 34.0 & 27.8 & 57.0 & 1.2 & -0.8 \\
\hline $55-60$ & 26.8 & 27.1 & 33.7 & 33.8 & 31.9 & 88.0 & 3.3 & 1.1 \\
\hline $50-55$ & 26.5 & 26.8 & 33.8 & 33.9 & 41.2 & 117.4 & 6.0 & 4.3 \\
\hline $45-50$ & 26.2 & 26.5 & 34.1 & 34.2 & 46.1 & 124.9 & 9.9 & 8.4 \\
\hline $40-45$ & 25.9 & 26.4 & 34.6 & 34.7 & 32.6 & 125.3 & 13.6 & 11.4 \\
\hline
\end{tabular}


Table 7: Significant maximum trends (per year) for Mixed Layer variables (+ indicates increasing trend, * indicates season in which maximum trend occurs).

\begin{tabular}{|c|c|c|c|c|}
\hline $\begin{array}{c}\text { Zone } \\
110-160^{\circ} \mathrm{E} \\
\text { by }\left({ }^{\circ} \mathrm{S}\right)\end{array}$ & $\begin{array}{l}\Delta \text { Mean } \\
\text { Depth } \\
\left(\mathrm{m} \mathrm{yr}^{-1}\right)\end{array}$ & $\begin{array}{c}\Delta \text { Mean } \\
\text { Temperature } \\
\left({ }^{\circ} \mathrm{C} \mathrm{yr}^{-1}\right) \\
\end{array}$ & $\begin{array}{c}\Delta \text { Mean } \\
\text { Density } \\
\left(\mathrm{kg} \mathrm{m}^{-3} \mathrm{yr}^{-1}\right)\end{array}$ & $\begin{array}{c}\Delta \text { Mean } \\
\text { Salinity } \\
\left(\mathrm{yr}^{-1}\right) \\
\end{array}$ \\
\hline $60-65$ & $\begin{array}{c}2.5 \times 10^{-1} \\
\operatorname{ALL}\left(\mathrm{MAM}^{*}\right)\end{array}$ & $\begin{array}{l}1.3 \times 10^{-2} \\
\mathrm{JJA}^{*}, \mathrm{SON}\end{array}$ & $\begin{array}{c}1.1 \times 10^{-3} \\
\text { DJF,MAM* }\end{array}$ & $\begin{array}{c}1.8 \times 10^{-3} \\
\text { ALL(DJF*) }\end{array}$ \\
\hline $55-60$ & $\begin{array}{c}6.2 \times 10^{-1} \\
\operatorname{ALL}\left(\mathrm{JJA}^{*}\right)\end{array}$ & $\begin{array}{c}1.8 \times 10^{-2} \\
\operatorname{ALL}\left(\mathrm{SON}^{*}\right)\end{array}$ & $\begin{array}{c}2.1 \times 10^{-3} \\
\text { ALL(DJF*) }\end{array}$ & $\begin{array}{c}3.2 \times 10^{-3} \\
\text { ALL(DJF*) }\end{array}$ \\
\hline $50-55$ & $\begin{array}{c}6.3 \times 10^{-1} \\
\operatorname{ALL}\left(J^{*} A^{*}\right)\end{array}$ & $\begin{array}{c}2.5 \times 10^{-2} \\
\operatorname{ALL}\left(\mathrm{SON}^{*}\right)\end{array}$ & $\begin{array}{c}2.9 \times 10^{-3} \\
\mathrm{ALL}\left(\mathrm{DJF}^{*}\right)\end{array}$ & $\begin{array}{c}5.2 \times 10^{-3} \\
\operatorname{ALL}\left(\mathrm{DJF}^{*}\right)\end{array}$ \\
\hline $45-50$ & $\begin{array}{c}8.9 \times 10^{-1} \\
\text { ALL }\left(\mathrm{SON}^{*}\right)\end{array}$ & $\begin{array}{c}2.6 \times 10^{-2} \\
\operatorname{ALL}\left(\mathrm{SON}^{*}\right)\end{array}$ & $\begin{array}{c}4.1 \times 10^{-3} \\
\operatorname{ALL}\left(\mathrm{DJF}^{*}\right)\end{array}$ & $\begin{array}{c}6.9 \times 10^{-3} \\
\text { ALL(DJF*) }\end{array}$ \\
\hline $40-45$ & $\begin{array}{c}4.5 \times 10^{-1} \\
\text { SON }^{*}\end{array}$ & $\begin{array}{c}1.3 \times 10^{-2} \\
\operatorname{ALL}\left(\mathrm{MAM}^{*}\right)\end{array}$ & $\begin{array}{c}-1.5 \times 10^{-3} \\
\text { MAM* }^{*}\end{array}$ & $\begin{array}{c}2.3 \times 10^{-3} \\
\mathrm{DJF}^{*}, \mathrm{SON}\end{array}$ \\
\hline
\end{tabular}


Table 8: Significant maximum trends per year, calculated as a percentage of the median value $(\mathrm{n} / \mathrm{s}=\mathrm{no}$ significant trend, $\mathrm{n} / \mathrm{a}=$ not applicable, $*$ indicates season in which maximum trend occurs.)

\begin{tabular}{|c|c|c|c|c|c|}
\hline $\begin{array}{c}\text { Zone } \\
110-160^{\circ} \mathrm{E} \\
\text { by }\end{array}$ & $60-65^{\circ} \mathrm{S}$ & $55-60^{\circ} \mathrm{S}$ & $50-55^{\circ} \mathrm{S}$ & $45-50^{\circ} \mathrm{S}$ & $40-45^{\circ} \mathrm{S}$ \\
\hline $\begin{array}{c}\text { UCDW } \\
\text { Vertical Velocity }\end{array}$ & $\begin{array}{c}0.53 \\
\text { MAM* }^{*}\end{array}$ & $\begin{array}{l}-0.35 \\
\text { SON* }\end{array}$ & $\begin{array}{c}0.40 \\
\text { ALL(DJF*) }\end{array}$ & $\begin{array}{c}0.78 \\
\text { ALL(MAM*) }\end{array}$ & $\begin{array}{c}1.3 \\
\text { ALL(DJF*) }\end{array}$ \\
\hline $\begin{array}{l}\text { UCDW } \\
\text { Top Depth }\end{array}$ & $\begin{array}{c}1.2 \\
\text { ALL(DJF*) }\end{array}$ & $\begin{array}{c}1.8 \\
\text { DJF*,MAM } \\
\text { JJA }\end{array}$ & $\begin{array}{c}0.34 \\
\text { MAM }^{*}\end{array}$ & $\begin{array}{l}0.45 /-0.05 \\
\text { DJF*JJA* }\end{array}$ & $\mathrm{n} / \mathrm{s}$ \\
\hline $\begin{array}{l}\text { Mixed Layer } \\
\text { Depth }\end{array}$ & $\begin{array}{c}0.71 \\
\text { ALL(DJF*) }\end{array}$ & $\begin{array}{c}0.70 \\
\operatorname{ALL}\left(J J A^{*} *\right)\end{array}$ & $\begin{array}{c}0.76 \\
\text { ALL(DJF*) }\end{array}$ & $\begin{array}{c}0.84 \\
\text { ALL(SON*) }\end{array}$ & $\begin{array}{c}0.41 \\
\text { SON* }\end{array}$ \\
\hline Stratification & $\begin{array}{c}-0.30 \\
\text { MAM,JJA* } \\
\text { SON }\end{array}$ & $\begin{array}{l}-0.24 \\
\text { MAM* }^{*}\end{array}$ & $\begin{array}{c}-0.66 \\
\text { DJF,MAM* } \\
\text { JJA }\end{array}$ & $\begin{array}{c}-0.77 \\
\text { DJF,MAM* } \\
\text { JJA }\end{array}$ & $\begin{array}{l}-0.67 \\
\text { SON* }\end{array}$ \\
\hline $\begin{array}{l}\text { Mean Wind } \\
\text { Stress }\end{array}$ & $\begin{array}{l}0.70 \\
\text { DJF** }\end{array}$ & $\mathrm{n} / \mathrm{s}$ & $\begin{array}{l}0.37 \\
\text { DJF* }\end{array}$ & $\begin{array}{c}0.41 \\
\text { DJF*,MAM } \\
\text { JJA }\end{array}$ & $\begin{array}{c}0.51 \\
\text { DJF*,MAM } \\
\text { JJA }\end{array}$ \\
\hline $\begin{array}{l}\text { Upward Ekman } \\
\text { Pumping Rate }\end{array}$ & $\begin{array}{c}0.74 /-0.40 \\
\mathrm{DJF}^{*} / \mathrm{SON}^{*}\end{array}$ & $\begin{array}{c}0.99 \\
\text { DJF*,MAM }\end{array}$ & $\mathrm{n} / \mathrm{a}$ & $\mathrm{n} / \mathrm{a}$ & $\mathrm{n} / \mathrm{a}$ \\
\hline $\begin{array}{c}\text { Northward } \\
\text { Ekman Transport }\end{array}$ & $\mathrm{n} / \mathrm{s}$ & $\begin{array}{l}-0.50 \\
\text { SON* }\end{array}$ & $\begin{array}{c}0.37 /-0.35 \\
\text { DJF*/SON* }^{*}\end{array}$ & $\begin{array}{c}0.50 \\
\text { DJF,JJA* }\end{array}$ & $\begin{array}{c}0.50 \\
\text { DJF*,JJA }\end{array}$ \\
\hline $\begin{array}{c}\text { Maximum } \\
\text { Wind Stress }\end{array}$ & $\begin{array}{c}0.36 \\
\text { DJF*,MAM }\end{array}$ & & & & \\
\hline
\end{tabular}

